Euskal ikerketen aldizkaria | Revue d'études basques |

Revista de estudios vascos | Basque studies review

$3 \mid 1998$

Numéro III

\title{
Gero liburuaren koherentziaz eta egituraketaz
}

\author{
Patxi Salaberri Muñoa
}

URL : https://journals.openedition.org/lapurdum/1717

DOI : 10.4000/lapurdum. 1717

ISSN : 1965-0655

Éditeur

IKER

Édition imprimée

Date de publication : 1 octobre 1998

Pagination : 241-271

ISBN : 2-84127-152-8

ISSN : 1273-3830

Référence électronique

Patxi Salaberri Muñoa, «Gero liburuaren koherentziaz eta egituraketaz», Lapurdum [Linean], 3 | 1998

Sarean emana----an 01 septembre 2010, kontsultatu 24 février 2022. URL: http://

journals.openedition.org/lapurdum/1717; DOI: https://doi.org/10.4000/lapurdum.1717 


\section{Patxi SALABERRI MUÑ̃A}

\section{GERO LIBURUAREN KOHERENTZIAZ ETA EGITURAKETAZ}

Irakurleak berehala atzeman dezakeen bezala, Axularren Gero liburuak bitara muga litezkeen hiru zati aski desberdin ditu oro har : batetik, hasierako hitzaurre moduko biak eta, bestetik, liburua bera, gerotik gerora ibiltzeak dakartzan kalteak eta berauen erremedioak agertzeko idatzi zen gorputz mardula.

Obraren azaleko lehen irakurketa erretorikoa egiten hasiz gero, beraz, bi dira exordio klasikoaren funtzioa edo' betetzen duten zatiak. Ildo horretarik, ohiko protasia edo liburuaren argumentuaren azalpena hasiera-hasieran agertuko da, hots, bai obraren eskaintza edo inbokazioa delakoan ("Gomendiozko karta"-n, alegia) eta bai "Irakurtzaileari" delakoan.

Gomendiozko kartak, dagokion izaerak horrela markatzen baitu, osagai panegiriko handia erakutsiko du, eta, gainerako eskaintzetan ohi bezala, liburuari eskaintzaren jasotzailearen araberako ospea eta prestigioa kutsatu nahi zaio, irakurleek ongi har dezaten eta, finean, arrakastatsua izan dadin. Guztiarekin ere, zuzenean "Irakurtzaileari" eskainitako testuari egokituko zaio exordioaren funtzio nagusia, bertan azalduko obraren gaia edo haria zein den adierazi baino lehen, exordioei dagokien captatio benevolentiae delakoa planteatuko baita. Ulergarria da, bada, Axularrek bi zatal hauetan jarri zuen arreta eta zehaztasuna.

Liburuaren corpus-ari dagokionez, eta egituraren aldetik erakusten bide dituen gora-beherak (anabasa, batzuen ustez) direla kari, arazo gaitzak ondorioztatu izan dira tradizionalki urdazubiarraren obraren azterketa eta balorapena egiteko orduan. Horrela, maizen plazaratu den lehen galdera ea ez ote zen Gero hau bi liburutarako prestatu materialaren zitu aldrebestua planteatzen zuena izan da. Bigarrena, lehenaren ondorio eta hura bezain latza nonbait, ea liburuak ba ote zuen liburu bezala kontsistentziarik (koherentziarik, lotura logikorik,...) galdetzen duena izan ohi da.

Arazo hauek zeharo argitzeak berebiziko zailtasunak dituela aldez aurretik dakigun arren (dokumentazio falta, etab.), bereziki saiatu nahi genuke ondoko lerrootan, aipatu galderei ahalik zehatzen erantzuten. 


\section{1 - LIBURUAREN EGITURA LOGIKOA FINKATZEKO AHALEGINAK}

Adierazi bezala, aspaldiko eztabaida da Axularrek bere liburuari eman zion egiturarena. Ezagun denez, liburuak hutsune nabarmenak erakusten ditu bai gaiaren joskurarena edo izan daitekeen arloan eta bai, era berean, esparru formalean.

Horrezaz gainera, ez da inolaz ere gutxiestekoa liburuaren azalean eta irakurtzaileari zuzendutako hitzaurrean bertan agertutako planteamenduarekin sortzen bide den kontraesana ere. Laburbilduz, azalean liburuak bi parte izango dituela esaten bada ere, hitzaurre moduko "Irakurtzaileari" delakoan aski garbi adierazten da bigarren partea ez dela momentuz argitaratuko, ez behintzat lehenengoarekin batera.

Jakina, hori horrela izanik, arras normala bide da iragarritako bi parteak inondik ere ez atzematea. Irakurle kualifikatu askok, alabaina, parte horiek nahasian ikusi izan uste dituzte obran zehar eta etengabe planteatu izan dute obraren anabasaren hipotesia.

Baina, aurreratu bezala, uste edo hipotesi hori areagotu egin izan da tematikoki ere kapitulu zenbaiten artean ohiko koherentzia irizpideetarako etenketa bortitzegiak ematen bide direlako (ez da beti kapituluen artean jarraipen zuzenik eskaintzen, etab.). Aldi berean, formalki kapitulu eta atal zenbaiten arteko konektoreen falta ere nabarmena da liburuan barrena, nahiz eta ezaguna den tematikoki loturarik ez duten atalen arteko sasikonexio formalak ere egin daitezken (definizioz konektore gramatikalak ${ }^{2}$ direnak erabiliz, esaterako); hau guztia, aurreko eta ondoko kapitulu eta atal zenbaitekin konektatzeko lokailuen faltan antzematen da.

Oro har, bada, liburuaren planteamendu orokorra zalantzaz zipriztindua agertu izan zaio irakurle zenbaiti eta, ondorioz, honek guztiak ikuspegi nahaste-borrastetsua ekartzen dio Gero-ri $i^{3}$. Urkijoren hitzetan agertzen den bezala,

.] con esta cuestión del orden en que están düpuestas [sic] las diversas materias de

la obra maestra de la literatura vasca se relaciona otro punto oscuro, cuyo esclarecimiento no deja de ofrecer ciertas dificultades (Urquijo 1912, 11)

Nolanahi ere den, zilegizkoa zaio ikertzaileari liburuaren egilearen asmoak eta metodoak finkatzen saiatzea eta, orobat, azken bertsio definitiboa moldatu zuenaren logika-ereduaz zenbait apunte egitea, liburuaren barne-koherentziaz galdetzea azken batean.

Ildo horretatik, beraz, kezka hedatua bezain onetsia izan da liburuaren egiazko "logika" bilatu nahi izatearena. Ahalegin horiek medio, oroitarazi beharrik ez dago, liburua "logikoago" bihurtzeko saiorik interesgarriena Intxausperena izan da ziurrenik ; era berean, beranduago etorriko zen Lafitterena bera ere harenaren ildotik abiatuko zen hein handi batean.

\section{1.- Intxausperen berrantolamendua (1864)}

Ezaguna da Inchauspek, bere ideologia erlijiosoak ezinbestean hartaratua nonbait, "expurgatu"-rik argitaratu zuela Axularren liburua. Halere, zalantzazkotzat 
antzematen zuen jatorrizko batasun haren antolamendu berria prestatzean, liburuaren barne logikaren lerro nagusiak utzi zituen agerian lehenbizikoz.

Guztiarekin ere, Intxauspek prestatu edizioaren "Aitzinsolhasa" izenekoan garbi asko plazaratu zituen obraren bi arazo nagusiak, hots, apailatzearen arduradunaren kezkarena eta, horren ondorioz, liburuaren egituraketan sortutako "nahasteka"-rena :

"Uste içateco da Iehen ekhoiztea edo edicionea etçuela Axularec guidatu eta arthatu ahal. Liburuaren baimenduetan ikhusten dugu orducotz etcela Saraco erretor : Nuper Rector de Sara..., Olim Reclor de Sara : Saraco erretor ohia, deithua da.

Horrec nabarbentcen du nola edicione hartan hainbertce huts eta narrio aurkhitcen den ; urhatsca trabatcen baitute iracurçaillea, eta ecin comprenituz gueldi arazten.

Liburuaren çathi guztien batundetcean ere bada cerbait nahasteca, eztira behar litezquen seguidan ibeniac.

Badirudi Axularen guthun edo paperac emanac içan cirela imprimaçailleari ondozcatu gabe, ordenan eçarri gabe ; eta hunec imprimatu dituela albeçala, escuen artean guerthatcen citçaizcan ereduraz, lehena azquen, azquena lehen ; etçuelacotz guidariric eta ez chuchençailleric" (Intxauspe 1864, vii-viii or.)

Baina Intxauspe ez zen arazoaren planteamendu hutsean geratu. Aitzitik, liburuaren haria finkatu, gaien arteko loturak bilatu eta, ondorioz, antolamendu berri bat ("bere baithaco ordena", azalean bertan zioenez) eman zion liburuari. Faltan nabari zuen jatorrizko logika bilatu nahi izatea baino ez zen izan haren ahaleginaren funtsa.

Horretarako, Axularrek azalean esandakoaren bidetik abiatu zen, liburua bi partetan banatuz eta konklusio gisako "Azkentza" atala bereiztuz. Hori bai, Axularrena zen "Irakurtzaileari" izeneko ataleko hitz deklaragarriei ("gero abisu haren arauaz, ethorkizunerat gobernatzeko" ziotenei, alegia) inolako kasurik egin gabe.

Gainerakoan, esan gabe doa banaketarako irizpideak ez zituela inon ere argitu Intxauspek. Edonola ere, edizio berriari ezarritako aurkibidearen bidez antzeman daitezke haren ahaleginaren ondorioak ${ }^{4}$ :

\section{Lehen partea : GFROTIARRAK}

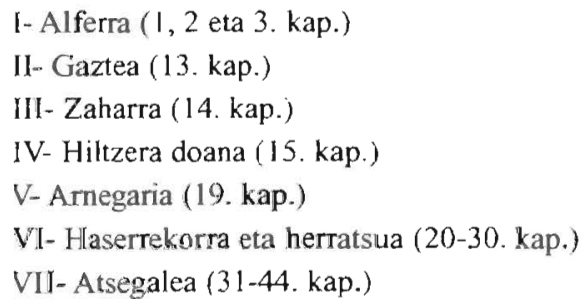

Bigarren partea : GEROTLARREN PIZGARRIAK

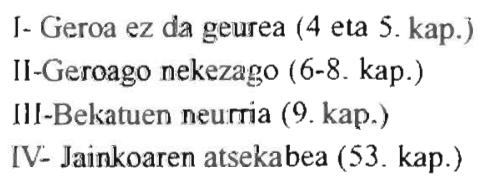




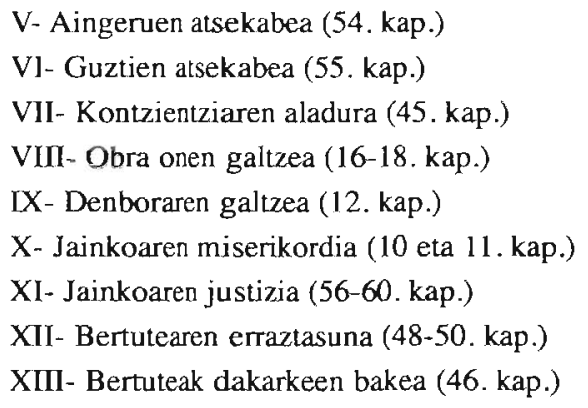

\section{AZKENTZA}

I- Behar dela konfesatu (5l eta 52. kap.)

II- Behar dela oniraun edo perseberatu (47. kap.)

Berehala soma daitekeen bezala, berrantolamendurako irizpideak tematikoformalak izan ziren nagusiki, inoiz zenbait kapituluren arteko ustezko loturei muzin egiten zitzaielarik.

Azpimarratzeko puntu interesgarria erakusten du Intxausperen egituraketa honek : kalonjea ongi ohartu zen esku artean zerabilen liburuaren blokeez, nolabaiteko autonomia erakusten duten bloke tematikoez esan nahi baita. Oro har, beraz, ongi "zatitu" zuen Intxauspek liburua (ikus "Egituraren zantzuak" atala).

Berrantolamendua, berriz, arazotsuagoa da, nahiz eta, oro har, lehenengo partean "bloke" moduan zalantzarik eskaintzen ez zuten atalak elkartu zituen Intxauspek "gerotiar" bide zirenen ildotik. Horrezaz gain, bigarren partean lortutako antolamendua ere ez zen izan Gero -ren lehen edizioarena baino hobeagoa, gure ustez.

Edozein modutan, antolamendu berriak ere ez zuen izan, geroago inspirazioiturritzat hartua izan zen Granadaren Guia de Pecadores liburuaren kointzidentziarik ere : "De aquí la nueva disposición de materias de la edición de 1864. Sea de esto lo que quiera, lo que puedo asegurar es que el orden adoptado por M. Inchauspe tampoco coincide con el de Fr. Luis de Granada" (Urquijo 1912, 11)

Nabarmentzekoa da Intxauspek "ienden delicatutasunagatic" (Intxauspe 1864, viii or.) egin zuen taxuketa interesatuak sobera agerian uzten dituela kalonjearen eskua eta izpiritua. Adibide gisa, Axularrek Neroni eskainitako lerro zaporetsuak (32. kap.) gozotasunik gabeko bihurtzen dira Intxausperenean, enperadore haren ama, "munduco emazteric prestuena" ez bide zen hura, ia martirologio kristauean sartzeko moduan utzi baitzuen kalonjeak.

\section{2.- Lafitteren berrantolamendua (1943)}

Ustezko anabasak eta logika tematikoaren faltak eraginda, badirudi Zünharreko kalonjearena bezalako kezka agertu zitzaiola Lafitteri ere : "Inchauspe zenarekin aitor dugu kapituluak guti-aski nahasiak direla. Ez bide ditu Axular-ek berak ordenu hortan ager-arazi” (Lafitte 1943, 26). 
Liburua irakurri ahala sortzen den inpresio horrek berdintsu jarraituko du handik hamahiru urtetara ere : "Liburua irakurtuz aise ageri ditake nor-nahiri, kapitulu guziak ez direla behar luketen lekuan. Nola behar litzaken ondozkatu eta elgarri jarrik-arazi, ez da argi-ere" (Lafitte 1956, 342).

Baina, hipotesi hori abiapuntutzat, Lafittek Intxauspek baino aurrerago egin zuen argitalpenaren arduradunen susmatze-kontuetan, izan ere Axularrek ez zuela argitaratze lanen erantzukizunik zabaldu bait.ruen, ezta azken apailaketarenik ere :

"[...] itchura askoren arabera, Axular-ek ez bide du berak (chaharregiz ala nik dakit-a ?) bere liburua argitarat eman : ilobak ala bertze norbaitek hartu dituzke eskuz eginikako gai guziak, lehen partekoak eta bigarrenekoak, elgarretarik berechi gabe, eta nolazpait bildurik ager-arazi" (Lafitte 1943, 28-29)

Era berean, urdazubiarrak liburuaren azalean agindutako bi parteen arazoari zegokionez, Lafittek honako hipotesi hau erantsi zuen :

"Beharrirat erraren (sic) dautzugu, gure iduriko, bigarren zathia, parte segurik, ez dugula batere galdua [...] lehen partekoak eta bigarrenekoak (gaiak, alegia), elgarretarik berechi gabe eta nolazpait bildurik ager-arazi (zituzten).

Bekatu zailenak eman dauzku eskutan dugun liburu ederrean; bainan ez bide zen lau bekatu hoitan gelditzekoa : ohointzaz bederen bazukeen kapitulu-alde on baten gaia.

Gure aburu osoa emaitekotz, erran ginezake Axular-ek ez zuela bere bigarren partea hasi baizik : sail handiari lotua zen [...] Damurik ez baitzuen bururatu!" (Lafitte 1943, 28-29).

Edozein modutan, eta esandakoak esan, badirudi Lafittek bukatugabetzat zuela liburua: "Itchuren arabera, Axular-ek bere lana bururatu balu, bertze jaidura gaixtoak ere jorratuko zituen -behinik behin, gezurra eta ohointza, - eta naski bertuteak ere goretsiko" (Lafitte 1956, 343)

Guztiarekin ere, ez bide zuen gustoko Intxausperen kapitulu-ordenamendua : "Inchauspé zenak bere gisako segida batean ezarri zituen, bainan bertze arrimurik asma ditake" (Lafitte 1956, 342). Eta, egia esan, beste bat asmatu zuen.

Laburturik, Lafitteren bildumaren berrantolatze hariak honako hauek izan ziren :

"[...] lehen parte batean Axular-ek erakusten dauku zertako ez den luzamendutan ibili behar :

Lehenik, geroko uzten den konbertsionea mentura tcharrean delakotz; alabainan geroa ez da gure eskuko, geroago eta nekezago da onerat itzultzea ;

Bigarrenekorik, gure bekatuzko estatuak zeru-lurrak histen ditu;

Hirugarrenekorik, bekatuan egoiteak dohakabe uzten gaitu; alabainan bihotza doluminez dauka bekatoreak; bekatuan higatu denbora galdua du; eternitatea galtzen du; ez du ezagutzen bertutearen gozorik.

Zathi hortarik jalgi ditaken chedea : kofesatu behar dela eta ongian iraun.

Bigarren zathian chehe-chehea ikertzen ditu lau bekatu nausi : alferkeria, zin egiteko usaia, haserrea eta lohikeria. Bakotchaz erraiten du nolako ondorioak dituen eta nola ditaken garait" (Lafitte 1956, 342-343) 
Irizpide horiekin, beraz, Gero liburuan azaltzen diren kapituluak honela barreiatuko ziren Lafitteren antolamendu berrian (ik. Lafitte 1943) ${ }^{\mathrm{s}}$ :

\section{A) Zertako ez den luzamendutan ibili behar}

I) Geroko uzten den konbertsionea mentura txarrean da

1.- Geroa ez da gure eskuko (IV-V)

a) bizitzeko segurantzarik ez dugu

b) menturari ez ditake fida

2.- Geroago eta nekezago da oneratzea (VI-IX)

Jainkoaren miserikordian ez othe ditake fida?

Ihardesten dio Axularr-ek (X-XI)

II) Gure bekatuzko estatuak zeru-lurrak trixkatzen ditu

1.- ?turuan (LIII-LIV)

2.- Lurrean (LV)

III) Bekatuan egoteak dohakabetzen gaitu

1.- Bihotza dolu-minez dago (XLV)

2.- Bekatutan higatu denbora galdua da (XII-XVI)

Bidenabar bi hitz justiziazko eta miserikordiazko obrez (XVII-XVIII)

3.- Eternitatea galtzen du bekatoreak (LVI-LVIII)

Artetik zuzen da ifernua betikoa izatea (LIX-LX)

4.- Bekatoreak ez dazagu bertutearen gozoa (XLVI eta XLVIII-L)

Xedea : Konfesatu behar da eta ongian iraun

1.- Penitentzia ontasuna da (LI)

2.- Usu kofesatu (LIl)

Iraupena (XLVII)

\section{B) Bekaturik zailenak}

I) Alferkeria (I-III)

II) Zin egiteko usaia (XIX)

III) Hasarrea eta herra $(X X-X X X)$

IV) Lizunkeria (XXXI-XLIV)

Ikusten denez, Lafittek estu-estu jarraitzen du Intxausperen "partiketa"; ondoko berrantolamendurako, berriz, nolabaiteko egitura-iraulketa eragin zion kalonjearenari, hau da, azken honek hasieran jarritakoa harek bukaeran ondozkatu eta alderantziz. Baina, edozein modutan ere, berdintsu jaso zituzten bi-biek logikoenak eta koherenteenak ziruditen "blokeak" eta, ordenatu ondoren, koherentziarik gabe gelditzen ziren hutsuneak beste kapituluekin estaltzen saiatu ziren.

Oro har, blokeak edo diren horiek Intxauspek Lafittek baino hobeto zatitu zituen arren, Lafittek harako hark kontutan hartu ez zuen elementu berri bat tartekatu zuen berrantolamendurako irizpidetzat, hots, bigarren partea lehenengoa- 
rekin nahasia bazen -eta horrela uste zuen berak-, liburuaren azalean Axularrek zioenaren araberako bigarren partea-edo izan zitekeenaren bukaeran kokatu behar omen ziren ezinbestean "bere eguin bideari lotu nahi çaicana"-ri eskaini beharrreko gidak eta erremedioak. Horretan oinarriturik, bada, Lafittek, bukaerara (bigarren partea osatzen zuen " $B$ " atalera, hain zuzen) pasatu zituen Intxauspek "Guerotiarrac" izenburupean hasiera-hasieran, lehen partea osatuz, kokatuta zeuzkan kapitulu gehienak (13, 14 eta 15.a izan ezik) : 1-3, 19, 20-30 eta 31-44, guztiak berdin-berdin ordenaturik.

Lafitteren lehen zatia osatzeko ere, bizpahiru aldaketa kenduta, Intxausperen ordena berbera erabiltzen da (ikus ondoko grafikoa).

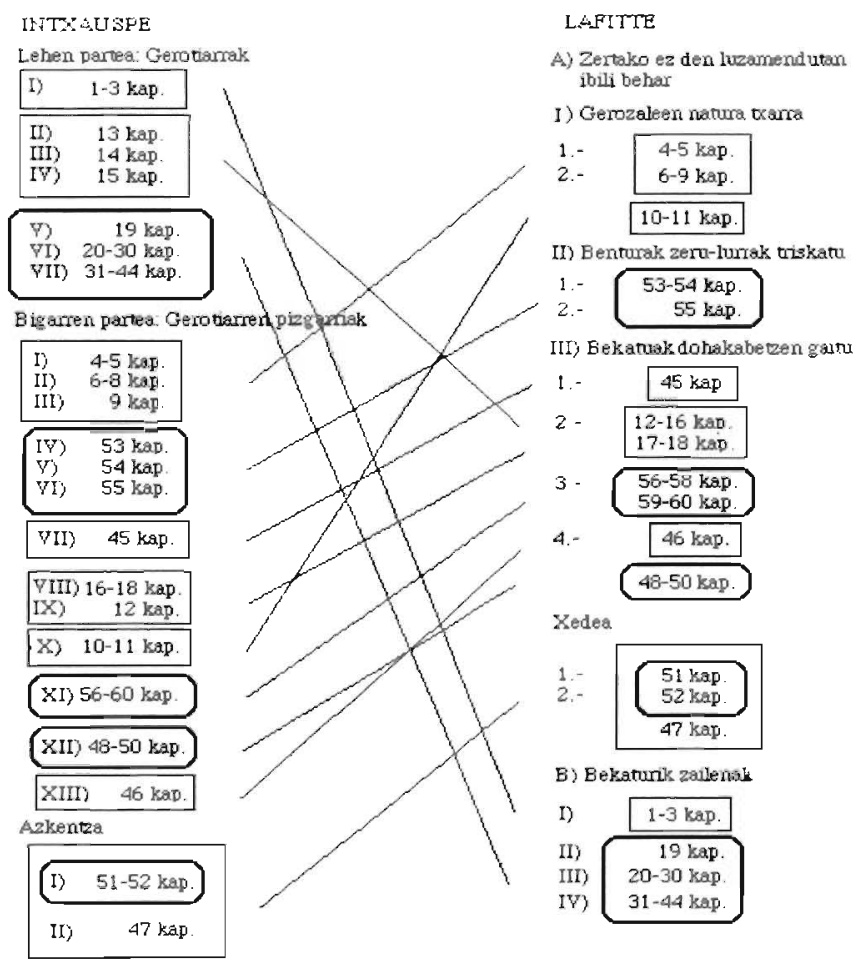

Gure ustez, dena den, Lafittek oker larriagoak egin zituen bere ondozkapena burutzean, besteak beste, liburuaren gaia zentratzen duten hasierako kapituluak (hasieran mantendu beharrekoak, alegia) lekuz kanpo jarri zituelako.

Are gehiago, antolatze-gida moduko honek, zehatza eta kapituluz kapitulu esplikatua izan zen arren, ez zituen kapituluen artean zeudekeen bestelako loturak aintzakotzat hartu, hau da, tematikoki ondozkatzen saiatu bai, saiatu zen autorea, baina beste hainbat faktore garrantzitsuri gehiegi begiratu gabe.

\section{2.- GERO-REN ANTOLAMENDUAZ}

Granadaren obrak maiz asko Axularren aurrean egon izan zirela jakin badakigun arren, aitortu beharrekoa da urdazubiarrak bere libururako proiektaturiko 
plan orokorrak urrun dirudiela domingotarrarenetik. Urkijok zioen bezala, “[...] fácilmente se echa de ver [...] que el plan que se propuso seguir Axular, distaba mucho del que próximamente un siglo antes de él, había escogido Granada" (Urquijo 1912, 8).

Inchauspek, Lafittek eta Urkixok bereziki erakutsi duten kezkarekin bat egin dezakegun arren, ez dugu uste berrantolamendu saiakerek ziturik eman dezaketenik ez bada aldez aurretik zenbait puntu garrantzitsu finkatzen.

Guketz, erretorika eta literaturaren ikuspuntutik interesgarriago iruditzen zaigu obran atzeman daitezkeen elementu pertinente ezberdinez jabetzea eta diren bezala azaltzea, balizko antolamenduaren arazoaren koordenadak dagokien lekuan kokatuz eta gainerako saiakera hipotetiko hutsetatik aldenduz.

\title{
2.1.- Axularren asmoak
}

Oro har, bi dira hemen nahasten diren arazoak : barne-koherentziarena, lehenengoa, eta, honekin estuki lotua doana, bigarrena, hots, liburuaren jatorrian bide zeuden bi parteak nahasirik argitaratuta ikusi omen dituzten autoreen planteamenduarena.

Biei erantzuten saiatuko garen arren, dagoeneko aurrera daiteke bigarrenak, bestelako daturik gabe, nekez izan dezakeela erantzun sendorik. Guztiarekin, bigarrenaren arlokoak dira ditugun lehenengo datuak, Axularrek zituen asmoen arazoa argitzen eta bideratzen hasteko dauzkagun zehatzenak hain zuzen. Ikus ditzagun :

a) liburuaren azalean obra bi partetan banatuko dela esaten zaigu :

"[...]bi partetan partitua eta berezia, lehenbizikoan emaiten da aidtzera [...] Bigarrenean kidatzen da eta aitzinatzen [...].

b) "Irakurtzaileari" eskainitako atalean, bestalde, lehenengo parte bat benturatuko duela dio urdazubiarrak, eta gero, agian bigarrena :

"Eta nahi nituzqueyen bi parteac elccarrequin, eta batetan athera. Baiña iccussiric cein gauça guti edireiten den euscaraz esquiribaturic, gogoan behartu naiz eta veldurtu, eztiren bideac asco segur eta garbi, baden bitartean, cenbait trabu edo behaztopa harri. Eta halatan hartu dut gogo, lehenbicico parte hunen, lehenic venturatçeco, eta berri iaquitera beçala aitcinerat igortceco. Hunec cer iragaiten den, cer beguitarte içaiten duen, eta nor nola mintço den, avisu eman diaçadan. Guero avisu haren arauaz, ethorquiçunerat governatceco : Eta bigarren partearen camporat atheratceco, edo barrenean guelditceco eta estaltceco" (16 or.)

d) Horiezaz gainera, exordio gisako hitzaurreen ondoren, liburua hasten den lekuan bertan honako izenburu nagusiarekin adieraziko da (adierazten jarraituko da !) egin gogo duena :

\author{
"GUERO \\ HASTEN DA GUE- \\ ROTIC GUERORA \\ dabillanaz, eguiten den, li- \\ buruaren lehen partea" (21 or.)
}


Honekin guztiarekin, bada, argi utzi behar da lehenengo kapitulua $(\mathrm{k})$ inprentara bidaltzean ere bi partetako asmoak irmo irauten zuela Axularrengan eta liburuaren lehenengo zatiaren argitaratzeari ekin ziola.

Halere, hiru lekuotan baieztatutakoa egia balitz ere, zalantzan geratzen zaio irakurleari ea nolakoa izango zen bigarren parte aitortu baina ezezagun hori, izan ere, tematikoki balizko bigarren liburukoa beharko zuena (edo beharko zuenaren zati garrantzitsua, bederen), zenbait aztertzaileri lehenengo honetan emana iruditzen baitzaie.

Ondorioz, aztertzaile horien bibliografia erabili duen irakurleari geratzen zaion susmoa ere ildo berekoa da : ez ote zen benetan (Axularrek berak aginduta edo, ziurrago izan daitekeena -baldin eta horrelakoetan ziurtasunik bada, bederen-, bestek bultzatuta) bi liburutarako prestaturiko materialea bakar batean argitaratzeko apailatu eta bakar batean argitara eman?.

Hipotesi hori areagotzeko, ezin da azpimarratu gabe utzi Axularrek bere obra adierazteko erabili zuen hipokoristiko baten kasua : "Eta hala deliberatu nuen, buru-eragotzkarri bezala, liburutto baten, bi partetan partiturik, gero hunen gaiñean egitera" (15-16 or. ; azpimarra gurea da). Ikusten denez, orain arte nabarmendua izan ez den atzizki txikigarri bat darabil, teorian -eta gutxienez ! - seiehun bat orrialdeko liburua izan behar zuen hura adierazteko.

Jakina, argitaratutakoa Axularren asmo-proiektuetan lehen partea baino izan behar ez bazen, nekez uler daiteke "liburrutto" delakoaren erabilpen erredundante hori ${ }^{6}$. Izan ere, atzizki txikigarrien zale ez zen autore batentzat (ez behintzat etengabe ikusmiran zuen Granadaren mailan) "liburutto" hitzak errealitate objektiboaz gain zebilen humilitas arloko topos hutsa erakutsiko luke? Ala benetako liburuska erabilgarriaren errealitatea (orrialde gutxiagokoa, alegia), gero bestek puztua eta apailatua?

Honek guztiak, dena den, Intxauspe-Lafitteren hipotesiaren bidetik sakontzen jarraitzeko elementua lirudike ziurrenik.

Nolanahi ere den, aurreko galdera sortak ez du oraingoz behin-betiko erantzunik izan. Eta, horrezaz gain, eman izan diren guztiak hipotesien erresumakoak gertatu dira.

Badirudi, beraz, izan zezakeen jatorrizko egituraren -baldin egon izan bada dugunaz besterik ! - pista bakarrak obran bertan bilatu beharko liratekeela, ez baitago tamalez bestelako informazio-iturririk (eskuizkriburik, besteren erreferentziarik,...). Eta, hortaz, aztarnok barne-koherentzian eta gaiaren taxuketan eta garapenean bilatu beharko lirateke nagusiki, hau da, inon agertzekotan, beharbada horiexetan baino ezin aurki litezke azalean iragarritako bi parteen arrastoak, zeren eta, azterketa estilistikoak eman dezakeenaren arabera ${ }^{7}$, sistema elokutibo koherente bakarra erakusten baitu obrak.

\section{2.- Gai taxuketaz}

Tematikoki egia da logika kartesiarraren printzipioen arabera bi partetan garbi bereizturik joan zitezkeen kapituluak (zenbat kalte egiten duen luzamendutan ibiltzeak, batetik, eta eginbidean bideratzeko gida, bestetik) nahasi moduan edo agertzen direla (arlo bateko kapituiu bat beste arloko beste kapitulu baten atzetik normalean) eta, ondorioz, indarra hartzen duela "anabasa"-ren hipotesiak. 
Honetan guztian, alabaina, badu Luis Granadakoaren obrak zerikusirik nonbait, haren irizpidearen parekoa baikenuke, iduriz, Axularrek izenburuan marraztu zuena. Areago, irizkidetasun hau Granadak landutako arlo teorikoan zein praktikoan eman zela baiezta liteke. Arlo teorikoari dagokionez, aszetikaz ihardun zuten beste autore askok bezalatsu, garbi utzi zuen eginkizuna :

"Luego pues que hubiere apartado al pecador de las malas obras, debe tambien exhortarle á las buenas, esto es, á todos los ejercicios de las virtudes, pincipalmente habiéndose de vencer los vicios con los actos de las virtudes opuestas" (Granada, Retórica, 524b ; azpimarrak gureak dira).

Eta zehatzagoa dirudi aurrerago esandakoak, formalki, sermoietan bezalatsu, liburuetan ere bekatuen arbuiatze bakoitzari bertutean jarraitzeko moduaren azalpenak segitu behar diola uler baitaiteke :

"[...] cuando hubiere exhortado al ejercicio de alguna virtud ó apartado de algun vicio, perorada la causa, muestre el modo con que deba prácticarse la obra de la virtud, ó huirse la acción torpe" (Retórica, 561a).

1556ko Guia de Pecadores delakoan ere badu planteamendu horren gauzatze praktikorik :

Tres cosas se requieren, cristiano lector, para hacer a un hombre verdaderamente bueno y virtuoso, que es el fin que la doctrina cristiana pretende. La primera es ganarle la voluntad y persuadirle que quiera y se determine a bien vivir. La segunda es enseñarle qué es lo que ha de hacer para bien vivir. La tercera, declararle cómo alcanzará fuerzas y espiritu para vivir esta manera de vida" (Guia, 1553:1953,9)

Ez da besterik Axularrek, azalean bertan adierazten duen bezala, bi liburutan burutu gogo duena :

"Lehenbicicoan emaiten da, aditcera, cenbat calte eguiten duen, luçamendutan ibiltceac, eguitecoen gueroco utzteac. Bigarrenean quidatcen da, eta aitcinatcen, luçamenduac utciric, bere hala, bere eguinbideari lotu nahi çaicana"

Horrezaz gain, Granadakoa oso zehatz mintzatu zen "gidatze-lan" horretan tratatu behar zenaz ${ }^{8}$ :

En primer lugar deberá estimular á aquellas que, á mas de ser virtudes insignes, sirven tambien muchisimo á excitar los deseos de las otras. En cuya clase señaladamente se colocan el continuo ejercicio de la oracion, la atenta meditacion de la pasion del Señor, y de los demas beneficios divinos, el frecuente uso de los sacramentos, la devota leccion de libros piadosos, la mortificacion de las pasiones, la guarda diligente y solicita del corazon, la afliccion de la carne, la moderacion de los sentidos exteriores, y mayormente de los ojos y de la lengua, con todas las obras de misericordia y humanidad, tanto corporales como espirituales, con que socorremos á nuestros prójimos" (Granada, Retórica, 524b).

Planteamenduaren eragin teoriko hori Gero honetan ere horrela gertatu izan balitz, urrun geundekeen Axularrek parte biak liburu bakar batean eman zituela esaten duen baieztapenetik.

Baina Granadakoaren alderdi teoriko hutsetik alde eginez, egiantzekotasun handikoa bide da honako hau ere, hots, metodologikoki Axularren obraren taxuketa zehatzean eragina izan zezakeela Granadaren aszetika libururik zabalduenak ere, harek bi liburutan banatu baitzuen bere Guia, bigarrenak Axularren bigarrena izan behar zuenarekin zerikusia izan zezakeelarik. 
Granadak bere Retórica liburuan, eta a posteriori izan bazen ere, aski garbi gomendatzen zuen "que cuando hubiere exhortado - predikariak - al ejercicio de alguna virtud ó apartado de algun vicio, [...] muestre el modo con que deba prácticarse la obra de la virtud, ó huirse la accion torpe. Porque dice muy bien Plutarco, "que los que convidan á la virtud, y no dan avisos para alcanzarla, son como los que atizan un candil, y no le echan aceite para que arda »" (Granada, Retórica, 561a)

Jakina, aldez aurretik horixe bera egina zuen Guia de pecadores delakoan, obraren hasierako hitzaurrean :

"Y según esto, se repartirá este libro -Guia osoaz ari da- en dos partes principales -bi liburutan alegia-. En la primera se declararán las obligaciones grandes que tenemos a la virtud, e los fructos e bienes inestimables que se siguen della; y en la segunda trataremos de la vida virtuosa, y de los avisos y documentos que para ella se requieren. Porque dos cosas son necesarias para hacer a un hombre virtuoso: la una, que quiera de verdad serlo, y la otra, que sepa de la manera que lo ha de ser; para la primera de las cuales servirá el primer libro y para la orra el segundo" (Granada, Guía, 11)

Lehen liburuaren aurkezpenean argumentazio hori areagotuko da : "Este Primero libro, cristiano lector, contiene una larga exhortación a la virtud" (Guia de pecadores, 14).

\section{Berdintsu adieraziko da bigarren liburuaren hasieran':}

"Porque no basta persuadir a un hombre que quiera ser virtuoso, si no le enseñamos cómo lo haya de ser; por tanto, ya que en el libro pasado alegamos tantas y tan graves razones para mover nuestro corazón al amor de la virtud será razón que agora descendamos a la práctica y uso della, dando diversos avisos y documentos que sirvan para hacer a un hombre verdaderamente virtuoso" (Granada, Guía, 121)

Halaz ere, garrantzitsuena lehenengo partea dela azpimarratuko du Granadakoak, hau da, Axularrek ere liburu gisa burutu zuen partea alegia :

"Mas con ser esta segunda parte tan necesaria, todavía lo es mucho más la primera ; porque para conocer lo bueno y lo malo la misma lumbre y la ley natural que con nosotros nace nos ayuda; mas para amar lo uno e aborrescer lo otro hay grandes contradicciones y impedimentos, que nacieron del pecado, así dentro como fuera del hombre [...] Por lo cual, romper por todas estas contradicciones e dificultades, y a pesar de la carne y de todos sus aliados, desear de veras y de todo corazón la virtud, no se puede negar sino que es cosa de grande dificultad y que ha menester socorro" (Granada, Guia, 11 or.)

Ondorio gisa, eta Luis Granadakoak egiten duen antzeko planteamenduaren aurrean, badirudi obraren taxuketan ere nolabaiteko parekotasuna edo antza behar duela egon. Are gehiago kontutan hartzen bada pasarte asko haren obretatik hartuak izan bide direla.

Jakina, Guia bakarrik ez da aski Axularrena zeharo esplikatzeko, ez egituraren aldetik, ez eta gaiaren aldetik ere. Urkijok adierazi zuen bezala (cfr. Urquijo 1912), Granadaren Guía-n dagoena eta Axularrena ez dira erabat parekagarri, baina bai -eta hau geuk diogu- hainbatetan argigarri.

Egituraren argitze kontu hauetan ezin da ahaztu Gero -ren giltza (azaleko aipamena) eta bukaera den aipua ere (Siraken Jakinduria 5) Granadaren Guia-ren lehen liburuko hirugarren partearen hasierako atalaren bukaeran agertzen dela han esandakoaren laburpen garrantzitsu gisa : 
"Y pues son tantos los que desta manera son castigados, muy mejor acuerdo será escarmentar en cabeza ajena y sacar de los peligros de los otros seguridad, tomando aquel tan sano consejo que nos da el Eclesiástico, diciendo (Eccli. 5) : Hijo, no tardes en convertirte al Señor, y no lo dilates de día en día ; porque súbitamente suele venir su ira, y destruirte ha en el tiempo de la venganza" (Granada, Guia, 92).

Axularrek Granadaren hitzok nagusiki modu literalean hartu zituela pentsa liteke -motiborik aski baitzeukan inondik ere harako gizatalde lapurtar osoak-, nahiz eta gero berak aipamenaren bigarren partea, bortitza eta mendekuzkoa benetan, isilpean gorde zuen. Azken batean, esaldi horren inguruan ardaztuko zuen urdazubiarrak bere liburua.

\section{3.- Linealtasun eta logika tematikoa}

Liburuak hirurogei kapitulu ditu, "zenbaki borobila", Schumann-ek dioen bezala, hirurogeia 5 eta 10 zenbakien multiploa baita (cfr. Curtius 1976, 705706). Hau, ordea, konstatazio bat baino ez litzateke eta ez luke derrigorrez aparteko sinbologiarik izan behar. Hori bai, egia da zenbait kapitulu erraz asko txerta zitezkeela aurreko-ondokoetan (gaiagatik edota laburtasunagatik) eta beste batzuk, aldiz, bitan-edo banatu, horrek ekar zezakeen kapitulu-kopuruaren aldaketarekin. Ez zen horrela egin; borobildu egin nahi izan zuten kapitulu kopurua eta hala eman argitara.

Kapitulu horien garapen mailaketari dagokionez, eskaintza eta aurkezpeneko lehenengo atal biak alboratuz, eta kapituluen tituluak kondentsaturik, oro har horrelako zerbait aterako litzaiguke argitaratu liburuan :

I-II : Alferkeria

ihes egiteko trabailatu behar da (I)

dagitzan kalteak : handiena gerotik gerora ibiltze (II)

III : Desirkunde utsetan iragaten zagi denbora

IV : ez dugu geroko segurantzarik

V-IX : geroan benturatzen gara eta

galtzen gara $(\mathrm{V})$

gaitzago dugu bekatutik ateratzeko (VI)

usantza gaixtoa hartzen dugu (VII)

honek ez antsiatzen eta gogortzen gaitu (VIII)

bekatuen neurria bete daiteke (IX)

$\mathrm{X}-\mathrm{XI}$ : Jainkoaren miserikordian

fidatu behar da $(X)$

ez da hargatik penitentzia geroko utzi behar (XI)

XII-XV : Gerotik gerora ibiltzean

denbora galtzen da penitentzia egiteko (XII)

baina batzuk zahartzarorako uzten dute (XIII)

zahartzean ere ez dute penitentzia egiten (XIV)

heriotzeko orduan penitentzia egin gabe (XV)

XVI-XVIII : Borondatezko eta obligaziozko obren probetxua

Borondatezkoa den erremusinarena (XVI)

orain egin behar, ez gero, eta zeuk (XVII)

Obligaziozkoak eta justiziazkoak, berdin (XVIII) 
XIX-XLIV : Bekatu buruzagi zenbait

XLV-XLVI : Kontzientzia gaixtoa eta ona

gaixtoaren liskarra (XLV)

onaren bakea (XLVI)

XLVII : Perseberatzea orain

XLVIII-L : Zein da bide errazagoa

paradisukoa ala infernukoa? (XLVIII)

paradisukoa errazagoa (XLIX)

infernukoak lan gehiago eta desatseginagoa (L)

LI-LII : Konfesatzea

lehen erremedioa (LI)

maiz egitearen probetxua (LII)

LIIf-LV : Bekatutan jarraitzeak bidegabe egiten dio

Jainkoari (LIII)

Aingeruei (LIV)

bere buruari, kristauei eta gauza guztiei (LV)

LVI-LX : Infermuko penen kontsideratzea

luzamenduak laburtzeko : pena damni (LVI)

pena sensus (LVII)

ilkitzeko esperantzarik eza (LVIII)

sekulako gaztigua (LIX)

barkamenik eza (LX)

Lehenengo begiradan harrigarri irudi lekigukeen arren, pizka bat sakonduz gero, Axularren liburuak nolabaiteko linealtasun tematiko bati jarraitzen diola ohar gaitezke. Edo, agian hobeto, oinarrizko linealtasun baten inguruan "eskurtsio" gisako adarreztaketak ematen dira Gero-n, joan-etorri moduko ibilaldiak nahi bada, abiapuntuek eta irispuntuek tematikoki eta, sarri askotan formalki ere, bat egiten dutelarik. Esan liteke erredundantziarik gehienak (ideienak, esaldienak, hitzenak, etab.) batze-puntu horietan suertatzen direla

Hasierako nahaste-borrastearen inguruko laharrak garbiturik, beraz, aski garbi ikusten da urdazubiarraren norabidea, "Irakurtzaileari" zuzendutako hitzetan aitortu gaiarekin :

"Ez du (..) deusec ere hanbat calte eguiten arimaco, eta ez gorputzeco ere, nola eguitecoen, gueroco utzteac" ( 15 or.).

Izan ere, kapitulu horien antolamendu orokorrak ba bide du norabiderik : abiaburua Genesisean legoke, hots, kreaturen sortzean berean, eta sekula bukatuko ez den infernuaren hausnarketarekin bukaera. Edo bestela adierazi nahi bada, obra honen egituraketa egungo parametroetatik ikusita aski nahasia bada ere, badira ohartarazteko hainbat puntu, azaletik antzematen ez den "koherentzia" antzeko bat ematen diotenak alegia :

* Lehen kapituluan, hasierako hitzak Genesis liburutik hartutakoak dira, kristauen Jainkoak gizona eta emakumea egin zituela adierazten duen pasartekoak, gizakiaren kreazioa, jaiotza. Sorrera horretan bertan kokatuko da gero gizakia kutsatuko duen alfertasuna/alferkeriaren arazoa. Beste modu batez esateko, liburuari Biblia -ren hasierarekin ekiten zaio, honako incipit honekin, liburu guztian 
barrena azalduko den gaiaren aurkezpena egiteaz gain, alfertasuna kreaturen sorrerarekin lotutakoa delako hipotesia abiapuntu bezala hartzen delarik.

* Modu berean, liburuaren bukaera eskatologikoan heriotza izango da gaia, benetako heriotza, infernura kondenatuta dagoenaren heriotza, "egiazko bizitza" lortzeko miserikordiarik izango ez duenarena.

* Hasiera eta bukaera biologiko-teologiko horren bitartean garatuko da liburua, bertan azalduko direlarik gizakiaren ezaugarri lurtiarrak (bekataria da) eta Jainkoarengana bihurtzeko bidea erakutsiko zaiolarik. Horrek guztiak bekatariaren hausnarketarako eta bizitzaren norabidea aldarazteko balio beharko zuen.

* Liburuan barrena, beraz, aipatu arazo horrek eta berau gainditzeko bideak osatuko dute mamia, baina onbideratze edo konbertsiorako mezu honetan, aldagai kronologikoa ("orain" vs "gero") izango da liburuari originaltasun kutsua eskainiko diotenetatik bat.

Axularren izenpean argitaratutako liburuak, beraz, bere "logikaz" taxutu zituen atalak eta kapituluak. Tartean antzeman daitezkeen inkonexio-deskonexioak, logikotasun ezak, etab. garai hartako hainbat libururi egotz dakizkiokeen tamainakoak izan litezke nonbait.

Nolanahi ere den, antolamenduaren logika horretan sakontzen hasiz gero, eta kapituluetako idazpuruek berek adierazten duten informazioaz baliatuz, linealtasun edo logika tematiko-formala izan dezakeen irakurketa berezia egin liteke, inondik ere. Hona hemen tituluetan oinarrituz egin ahal izan dugun irakurketarik trinkoena ${ }^{10}$ :

Munduko saindu, jakintsu eta gauza guztiek kondenatzen duten alferkeriatik ateratzeko trabailatu egin behar da (1. kap.). Eta arrazoia da alferkeriak kalteak baino ez dituela berarekin ekartzen (gaixtakeria, pobrezia,...), kalterik handiena gauza guztietan (baita arimarenetan ere) gerotik gerora ibiltzea delarik (2. kap.).

Egia da bekatore nagia horretaz ohartzen dela, baina, bere nagikeriaren ondorio zuzenez, denbora desirkunde hutsetan iragaiten zaio (3. kap.). Eta ematen du gerorako uzte horrekin ez dela benetan konturatzen inork ez duela geroko segurantzarik (4. kap.). Areago, pertsona alferra (gu geu, alegia) benturaren benturan benturatzen da, fidatu egiten da geroaz eta luzamenduez (5. kap.).

Eta, jakina, geroago gaitzago da bekatu egoeratik ilkitzea (6. kap.), horrela ibiltzearen ondorio gisa usantza gaixtoa hartzen baita (7. kap.). Eta, ez dago zalantzarik, usantza gaixtoaren indarrak gogortu, itsutu eta ez antsiatu egiten du bekatorea, hots, alferra (8. kap.).

Baina ez dira horiek gerotik gerora ibiltzearen kalte bakarrak : ezin da ahaztu Jainkoak norberari markatutako denboraren iraupena buka daitekeen bezala, bekatuen kontua eta neurria ere, bekatu-kopurua alegia, osatu eta bete egin daitekeela horrela (9. kap.).

Egoera honetatik ateratzeko, asko balio du Jainkoaren miserikordiak eta hartan fidatu behar da (10. kap.), baina beti ere fidatze horretan pasatu gabe" eta egin beharreko penitentzia (eta obra onak ${ }^{12}$ ) geroko uzten ez d (ir) elarik, ezen miserikordia justiziarekin orekatzen baitu Jainkoak (11. kap.). 
Hau guztia (konbertitzea, penitentzia, obra onak) lehenbailehen egin behar da, "fite presenteon"', denbora galdu baino ez da egiten gerotik gerora ibiltzeaz ( 12 . kap.). Horrela, gazte-denboran ez da penitentzia zahartzeraino luzatu behar (13. kap.). Baina luzatu duenak gaizki egingo du zahartzean ere penitentziarik egiten ez badu, "hura emaçu galdutçat"' , berandu baita aztura gaixtoak uzten hasteko (14. kap.). Halere, okerragoa da oraindik heriotzeko oreneraino bekatutan egon gogo duenaren egoera, nahiz eta itxaropenik ezin den galdu; izan ere, bekatua ezabatzeko aski diren Jainkoaren grazia eta bekatariaren borondatea, eta horiek guztiak "eguin ditezque laburzqui, heriotceco azquen articuluan (...) heriotceco pontuan ere, azquen orenean ere"'s bertan (15. kap.).

Halaber, gogoratu behar da penitentziarekin batera bestelako obra batzuk ere egin behar izaten direla arima salbatzeko. Borondatezko eta miserikordiazko obren artean probetxu handienetako bat da erremusina egitea (16. kap.). Hori bai, nork bere eskuz eta ondokoetara utzi gabe egin behar dira erremusinak eta beste obra on borondatezko guztiak baliagarriago izan daitezen (17. kap.). Era berean, justiziazko obrak, obligaziozkoak, kontzientziaz zor direnak alegia, ondokoetara utzi gabe egin behar dira (18. kap.).

Bekatuen artean badira espreski aipatu beharreko batzuk, zeinetan luzamendutan ibiltzeak eta erremedioak geroko uzteak kalte larriagoak egiten baititu. Guztietatik lehenbailehen, geroko luzatu gabe, ateratzea aholkatzen du saratarrak. Hona hemen bekatuok:

Juramentuak egin ohi dituen kalteak eta usantza horretatik ilkitzeko erremedioak (19. kap.).

Kolerak eta etsaigoak egiten dituzten kalteak (20. kap.) eta ez haserretzeko, mendekuak bertan behera uzteko eta kolera iraungitzeko erremedioak $(21,22,23$, $24,25,26$ eta 27. kap.). Areago, etsaiari barkatu egin behar zaio eta amorio eduki, hots, onetsi eta maitatu $(28,29$ eta 30 . kap.).

Haragiaren bekatuak egin ohi dituen kalteak eta ematen dituen egitekoak ( 31 , $32,33,34$. kap.) eta bekatu horretatik begiratzeko bideak eta erremedioak ( 35 , $36,37,38,39,40,41,42,43$ eta 44 . kap.).

Ongi egitera bultzatu eta gaizki egitetik hastandu egiten gaituen beste bide bat ere -arrazoi naturala edo kontzientzia alegia- gaixtatu egiten da luzamendutan eta gerotik gerora ibiliz gero (45. kap.). Areago, kontzientzia onak mundu honetan bertan eskaintzen dituen bakea, sosegua eta arraitasuna bera ere galdu egiten dira kontzientziaren gaiztatzearekin, gerotik gerora ibiltzearen ondorioarekin hain zuzen (46. kap.).

Ildo horretatik, arimaren salbamendua eta parabisua erdiesteko perseberatzen saiatu behar da geroko begira egon gabe, hau da, bekaturik gabe egoten eta bertutean eta ontasuenan irauten (47. kap.).

Baina zaila ote da ontasun horretatik, hau da, bizitze on batetik hobeagora, parabisu honetatik sekulako loriara joatea ? ${ }^{16}$ Infernuko bidea parabisukoa baino errazago eta atseginagoa dirudien arren (48. kap.), frogatu egiten da nola parabisuko bidea den erraza (49. kap.) eta, gainera, nola den infernukoa baino errazagoa (50. kap.). 
Arima salbatzeko ezinbestekoa den konfesatzea ez da geroko luzatu behar ( 51 . kap.). Gainera, maiz konfesatu behar da, handiak baitira handik heltzen diren probetxuak (52. kap.).

Gerotik gerora luzamendutan ibiltzea guztiei bidegabe egitea da : Jainkoari (53. kap.), Aingeruei (54. kap.), nork bere buruari, giristino lagunari eta bai munduko beste gauza guztiei ere (55. kap.).

Luzamendutan ibiltzeak egiten dituen kalteen artean handiena sekulako, hots, infernuko penetara egoztea denez gero, erremediorik egokiena infernuko pena horiek beroiek kontsideratzea baino ez da. Horrela, infernuko beldurrak gerotik gerora ibiltzeko luzamenduak laburtzea ekar lezake (56. eta 57. kap.). Baina pena izugarri horiezaz gain, gogoan hartu behar da eta kontsideratu infernuan daudenek ez dutela handik ilkitzeko esperantzarik (58. kap.) Era berean, hartaratzeko bekatua denbora apurrean eta laburrean egina izan den arren, badira arrazoiak hain gaztigu handia, luzea eta sekulakoa emateko (59. kap.), Jainko miserikordiosak infernuan daudenei denboraren buruan ez barkatzeko badiren bezalaxe (60. kap.).

Ikusten denez, nabarmena da liburuan barrena agertzen diren bloke tematiko desberdinen presentzia eta, era berean, horietako zenbaiten artean agerian dagoen hausketena -edo sasi-hausketena, nahiago bada-. Izan ere, kapitulu eta kapitulusorta batzuen ondoren sortzen diren etenketak medio, kapitulu zenbaitek guretzat logiko diren irizpiderik gabe pilatuta daudela dirudite.

Lehenengo begiradan, beraz, badirudi obra honek ez lukeela testuen koherentziaz testu linguistikak ulertzen duena zeharo beteko :

"Tendremos un texto coherente, si el referente de cada proposición tiene al menos una vinculación de posibilidad/probabilidad/necesidad de co-ocurrencia con el hecho denotado por la macroestructura" (A. Ferrara, 1976 ; apud Oleza, 1981, 181 or., 2. oh.)

Egia da alabaina posibilitate-probabilitate-premiazko loturaren kontzeptu horrek nahiko eremu zabala har dezakeela eta modu ez-hertsian interpreta litekeela, ez baita aszetika gaia eta arloa testu baten makroestrukturak gehiegi defini ditzakeen horietarikoa, testu narratibo edota poetiko baten kasuan gertatzen den bezala. Izan ere, aszetikaren helburu pragmatikoekin batera joan daiteke -horrela uler daiteke, bederen- gai baten inguruko ia etengabeko erredundantzia eta, zenbaitetan, logikotasun kartesiarretik at dagokeen gai-adarreztaketa bera ere.

Honelakoetan, metodologikoki eta gehien bat edizio kritikoen apailatze lanetarako azpimarratu ohi diren ideien haritik abiatu behar dela dirudi, hau da, koherentzia edota logikotasunaren erlatibizazioa onetsiz. Igancio Arellanok isladatzen duen bezala,

..] es preciso estar en guardia ante el peligro de aplicar criterios de " coherencia » actual a textos del Siglo de Oro que estaban regidos por otras coherencias, las cuales podemos destruir en tanto no las captemos con claridad (Arellano 1991, 570)

Berdintsu jokatu beharko genuke honako honetan ere ziurrenik.

\section{3.- EGITURAREN ZANTZUAK}

Orain arte arakatutakoaren arabera, zinez esan daiteke liburuaren irakurketa tematiko-formalak agerian uzten dituela desberdinak diren atalak, elkarren artean 
lotura gehiegirik gabekoak diruditenak, eta, areago dena, zenbaitetan kapitulu hutsen gaineko funtzionamendua dutenak. Izan ere, aipatutako parte horiek elementu aski autonomo bezala agertzen dira, besteak beste ez dagoelako bloke "autonomo" horien artean ez lotura hitzik ezta tematikoki erlaziona zezakeen esapiderik ere. Gainera, esan bezala, maiz kapituluen nortasuna bera ere irensten dutela dirudi, parte bakoitzak bere bukaera propioa izatera iritsi baitaiteke.

Egitate horretan oinarriturik, hipotesi antzeko bat planteatu beharko litzateke liburuaren izaera esplikatu ahal izateko. Ildo horretatik, ez dirudi ausartegia litzatekeenik pentsatzea -eta horren demostrazioan saiatu beharko dugu orriotanAxularrek sare, ehun edo eskema antzeko bat prestatu zuela inoren obran oinarrituta, eta gero eskema hori osatuz joan zela erretorikak eskaintzen zizkion bitartekoak erabiliz.

\section{1.- Kapitulu multzoak}

Kapitulu multzoak esatean, haien artean lotura estua (ez beti erabatekoa) dutenak adierazi nahi dira. Kapitulu-multzo moduan hartu ditugun bloke hauen ezaugarri nagusiak honako hiru hauetara laburbil litezke : alde batetik, gai berdintasuna izango da horrelakoetan agerian geratuko dena, bai gai bakar baten garapena egiten denean eta bai horren inguruko ikuspuntu desberdinen azalpena burutzean. Horrezaz gain, multzoa osatzen duten kapituluen arteko loturak nabarmenak dira, hari tematikoak (ideiak, hitzak,...) errepikatu egiten baitira aurrekoen bukaeran edo ondokoen hasieran. Azkenik, nabaria da zenbaitetan kapitulu-multzoaren bukaera laburbiltzaile bakarra.

1.- Oro har, Gero liburua dagoen-dagoenean hartuta, honako hauek lirateke bereiztu beharko genituzeen bloke autonomo nagusiak :

I-XV. kap. : Konbertsioaren (penitentziaren) atzeratzea, denbora galtzea faktorearekin loturik agertuko da. (21-218 or.)

XVI-XVIII. kap. : Konbertsio prozesurako lehen urratsak : borondatezko obrak eta obligaziozkoak. Borondatezko obra onak (erremusina, batik bat) eta justiziazkoak eta obligaziozkoak behar-beharrezkoak dira eta ez dira ondokoek egin ditzaten utzi behar (219-249 or.).

XIX-XLIV. kap. : Bekatu buruzagi zenbaiten kalteak eta haien aurkako erremedioak (kolera, haragia, etab.) tratatzen dira (250-419 or.). Ohiko aszetika liburuetan elkarren ondoan joaten ez badira ere (ik. Granadakoaren Guía), honako honetan Axularrek jarraian eskaintzen ditu duten lotura tematikoagatik.

XLV-XLVII. kap. : Konbertsioaren atzeratzea kontzientzia faktorearekin loturik : kontzientzia gaixtoa $v s$ ona- $>$ pertseberatzeko beharra (419-473 or.).

XLVIII-L. kap. : Paradisura joatea errazago da infernuratzea baino (474-522 or.).

LI-LV. kap. : Penitentzia (eta haren praxia : konfesioa) ezinbestekoa da ; bestela, atzeratzearekin bidegabe egiten zaie guztiei : Jainkoari, aingeruei eta kreatura guztiei (523-569 or.).

LVI-LX. kap. : Azkenkien kontsiderazioa, konbertsiorako bidea : infernuaz (569-621 or.). 
Esan bezala, multzo bakoitzak bere autonomia du eta osotasun antzeko bat erakusten du: esanahi eta tematika zehatza, zenbaitetan hasiera-bukaera propioak, etab. Baina dena esatekotan, lotura logikoen arazoa ere multzo hauen artean legoke nagusiki.

2.- Halere, multzo bezala desberdinak izateaz gain, badirudi eraginetan ere iturri edo irakurketa desberdinetatik sortuak direla, izan ere, kapituluen irakurketa sakonago bat eginez, berehala antzemango baita liburuaren dispositio-ak baduela zerikusirik inventio arloan ikusitako sortze prozesuarekin, paralelismoen atalean agertutako zenbait iturrirekin hain zuzen.

Hari honetatik jarraituz, zinetan esan daiteke Gero obra desberdinetako ereduen arabera sortutako materialez osatua dagoela, eta koherentzia orokorra Granadarena bezalako planteamendu batetik datorrela.

Begirada testu kidetasunen atalera zuzenduz gero, irakurlea berehala ohartuko da eragin eta kidetasunak honela banatzen direla nagusiki :

- Lehenengo kapitulu-multzotzat hartutakoan aurkitutako kidetasunek Guía dute iturri.

- Orobat, XVI-XVIII. kapituluetan Oración y Meditación liburua da paralelismo guztien artean biziki nabarmentzen dena, batik bat XVI. eta XVII. kapituluei dagokienez.

- XIX-XLIV. bitarteko kapituluak, zalantzarik gabe, askeenak dira kidetasun eta paralelismo kontuan. Bertan Guia-ren aztarna garrantzitsuak agertu arren, ohiko liburu aszetikoetatik jasotako material "topiko eta tipiko"-aren arabera moldatua dirudi. Horrez gain, metodologikoki ere, burutzeko zailtasun gutxien eskaintzen duena bide da, oso gai garatuak baitziren literatura mota honetan.

- Berdin adierazi beharko litzateke XLV. eta XLVI. kapituluei buruz. Halere, XIVII. kapituluan Memorial delakoaren kidetasun bitxirik ere aurkitu izan dugu (Gero, 470-471 or.).

- Gutxi batzuk baino ez dira hurrengo kapitulu-multzoan (XLVIII-L. kap.) aurkitutako paralelismoak eta kidetasunak eta, ohi bezalaxe, denak Guia delakoarenak bezalakoak.

- Konfesioaren atalean (LI-LV. kap.) iturrien arazoa ez da argia ; halaz ere, azken kapituluan nabarmena dirudi San Agustinen testuen erabilera zuzenak.

- Azkenik, LVI.-LVIII. kapituluetan azpimarratzekoa da Memorial delako liburuaren presentzia naroa. Ez horrela azken kapitulu bietan.

Baina paralelismo edota kidetasun erabakior hauezaz guztiez gain, ezin ahaz liteke Granadaren obrak Axularren kapitulu askoren taxuketarako erreferentzia orokor gisa suposatu uste duena.

Orain arte esan dugunaren ildotik, eta Gero liburuaren planteamendua ulertzeko Granadaren aipatutako obrak argigarri badira ere, lehen kapitulu-multzoen ehunduraz ohartzeko ezinbestekoa da Guia de pecadores delakoaren lehen liburuaren 3. partearen hasieran dauden hitzak irakurtzea, bertan esaten denarekin esplikatzen bide baita, neurri handi batean bederen, Axularren egituraketaren atal garrantzitsu bat. Luze samarra den arren, hona hemen pasartea : 
"Ninguna duda hay sino que lo que hasta aqui habemos dicho bastaba y sobraba para el principal propósito que aqui pretendemos, que es inclinar los corazones de los hombres, supuesta la divina gracia, al amor y seguimiento de la virtud. Mas con ser todo esto verdad, no faitan a la malicia humana excusas y aparentes razones con que defenderse o consolarse en sus males, como afirma el Eclesiástico, diciendo [Eccli., 32.] : El hombre pecador huirá de la corrección, y nunca le faltará para su mal propósito alguna aparente razón. Y Salomón otrosi dice que anda buscando achaques y ocasiones el que se quiere apartar de su amigo ; y así los buscan los malos para apartarse de Dios, alegando para esto cada uno su manera de excusa. Porque unos dilatan este negocio para adelante: otros le reservan para la hora de la muerte; otros dicen que recelan esta jornada, por parecerles trabajosa ; y otros, que se consuelan con la esperanza de la divina misericordia, pareciéndoles que con sola la fe y esperanza, sin caridad, podrán salvarse y otros, finalmente, presos con el amor del mundo, no quieren dejar la felicidad que en él poseen, por la que les promete la palabra de Dios. Estos son los más comunes embaimientos y engaños con que el enemigo del linaje humano de tal manera trastorna los entendimientos de los hombres, que los tiene cuasi toda la vida captivos en sus pecados; para que en este miserable estado los saltee la muerte, tomándolos con el hurteo en las manos. Pues a estos engaños responderemos ahora en la postrera parte deste libro, y primero contra los que dilatan este negocio para adelante, que es el más general de todos éstos" (Granada, Guia, 9l or. ; azpimarrak gureak dira)

Garbi ikusten da testu honetan horretaz ihardun duela Axularrek berak ere, eskema berdintsua erabiliz : lehenengo, Granadaren hitzetan, "contra los que dilatan este negocio para adelante" arituko da (Gero, I-XIV kapituluak), tartean (XXI kapituluetan, hain zuzen) Jainkoaren miserikordiaren esperantzarekin kontsolatzen direnei zuzentzen zaielarik. Hauei "con sola la fe y esperanza, sin caridad, podrán salvarse" iruditzen zaienez gero, XVI-XVIII. kapituluak eskaintzen dizkie oker horretatik ateratzeko. Era berean, aipatu "negozioa" heriotzeraino atzeratzen dutenentzat ere badago tokirik (XV. kap.). Liburuaren zatirik mardulena, dena den, Granadaren esanetan "presos con el amor del mundo" daudenei zuzenduko die Axularrek, hain zuzen ere "bekatu buruzagiak" izenekoei (Materreren izendapena erabiltzeko) atxikirik bizi direnei (XIX-XLIV kap.).

Nolanahi ere den, garbi bereiztu nahi genituzke hemen azpi-ehundura teorikoa eta paralelismo zehatzak, izan ere, egitura aldetik antz handia erakuts dezaketen arren, kapitulu askok (erremedioei buruzkoak, besteak beste) tratamendu eta toki desberdina ager baitezakete Axularrenean eta Granadarenean.

Egia aitortuz, Granadaren behin-betiko Guia-ren taxuketa oso ondo pentsatua eta mugatua zegoen, esku artean darabilgun Gero delako hau baino gehiago ziurrenik, nahasiago eta ez hain orekatuta agertzen baitira Axularrenean gaiak ${ }^{17}$.

\section{2.- Azpimultzoak}

Edonola ere, goian marraztu diren kapitulu-multzo orokor horiek tematikoki autonomia eta mugikortasun gehiagoko bigarren mailaketa bat ere onartuko luketela dirudi. Gainera, azpimultzo gisa hartuko ditugun horiek izaera trinkoago erakutsiko dute barrenean, eta maiz asko kapitulu solte moduan baino egitura osoagoa dute elkarrekin jarrita eta bakar bat balira bezala kontsideraturik.

Azpimultzo horien adierazgarria, beraz, batasun tematikoa, elkarren arteko lotura formala eta garapen bakarra izango dira nagusiki.

Konparazio arrunt batek erakusten duenez, berauek izan ziren, irizpide arloko gora-behera zenbait keduta, Intxauspe eta Lafitteren berrantolamenduetan ondozkapena bideratzeko unitate garrantzitsuenak. 
Honako hauek dira nabarmenenak ${ }^{18}$ :

1. eta 2. kapituluak. Alferkeriatik ihes egiteko trabailatu egin behar da, bestela handik gerotik gerora ibiltzea sortu daitekeelako.

5,6,7 eta 8. kapituluak. Geroko benturan benturaturik, geroago gaitzago da bekatutik ilkitzea, usantza gaixtoa hartzen baita. Usantza honek gogortu eta ezantsiatu egiten du bekatorea.

10 eta 11 . kapituluak. Protestantismoak zabaldutako fedearen bidezko salbazioaren aurkako planteamendua: Jainkoaren miserikordian fidatu behar da ( 10 . kap.) baina ez sobera, neurriz baizik, hots, aztura gaixtoak utziz eta obra onak eta penitentzia eginez (11. kap.).

Unitate gisa hartzeko arrazoi nabarmenena tematika beraren bi ikuspunturen garapena izatean datza.

13, 14 eta 15. kapituluak. Penitentzia zahartzaroraino luzatzen dutenak, zahartzean ere egiten ez dutenak eta heriotzeko orduan bekatutan egon gogo dutenak erokeriatan ari dira, betirako galtzeko arrisku handia dute.

16, 17 eta 18. kapituluak (ikus kapitulu-multzoetan esandakoa).

19-44 bitarteko kapituluak (Ikus kapitulu-multzoan esandakoa).

45. eta 46. kapituluak. Gerotik gerora ibiltzeak kontzientziari dakarzkion kalteak : kontzientzia gaixtoa alatu egiten da eta kontzientzia onak bakea eta sosegua galtzen du.

48, 49 eta 50. kapituluak (ikus kapitulu-multzoei buruz esandakoa).

51. eta 52. kapituluak. Konfesatzearen premiaz eta handik sortzen diren probetxuez.

53,54 eta 55. kapituluak. Gerotik gerora ibiltzean jainkoari, aingeruei eta kriatura guztiei egiten zaien bidegabeaz.

56-60 bitarteko kapituluak (ikus kapitulu-multzoei buruz esandakoa).

\section{3. - Gai lokailuak}

Argumentazioaren garapenerako hain garrantzitsu diren gai konektore edo lokailu hauek ${ }^{19}$ (kapituluen artekoek, alegia) testuaren beraren koherentziaz eta taxutze-logikaz mintzatzen zaizkigu berez.

Esku artean dugun liburuan, "gerotik gerora" formularen bitartez egiten diren lotura tematikoez gain, bi motatako gai konektoreak ediren ditugu nagusiki :

1.- Obraren egituraketan atal desberdinak uztartzeko erabilitakoak. Interesgarrienetariko bat honako hau genuke :

"Bethi ere, lehenbizitik hartu dugun xedeari, ahal bezanbat, authikitzen dioguela, hari iarraikitzen gatzaitzala, hartara destatzen eta enkaratzen garela, edirenen dugu gure gero hunek presuna [...] artean ere baduela bere ostatua eta iarlekua, hetan ere kalte handiak egiten dituela" ( 270 or.)

Ikusten denez, lokarri honek bekatu buruzagi zehatz batzuetarako jarria bada ere, bekatu guztien txertaketa justifikatzeko ere balioko luke oro har. 
2.- Kapituluen arteko lotura dagitenak, normalean ondoko gaia bideratzen duten aurretiko antzekoak. Kapituluaren izenburuan bertan aurki daitezke edota kapituluaren garapenean bertan, ondoren etorriko dena zein izan daitekeen adieraziz. Askotan ondoko kapituluan ere horren erreferentzia egin ohi da. Azken finean, gaiaren garapenean dagokeen logika areagotzera etorriko lirateke "lokailu" hauek.

Luze joko luke gai konektore guztiak hona ekartzeak eta, arlo taxonomikoa areagotzeaz salbu, zerrendatzeak ez luke bestelako funtziorik. Esan, dena den, konektore tematikoen adibide argigarrienak azpimultzo gisa hartu diren horien artekoak ditugula, 5.etik 8.era bitarteko kapituluetan ikusten den bezala :

5. kap.- 6. kap.

5. kap. : bentura motak zer diren azaldu ondoren, txarrena baztertu eta konbertitzeko gonbitea, "beccatutaric iltqui çaiteci" (76 or.) mezua. burua.

6. kap. : “... gueroago gaitzago, beccaturic ilquitcea” (77 or.) da kapituluaren izen-

6. kap. - > 7. kap. .

6. kap. : bekatutik ilkitzea geroago gaitzago bide da, besteak beste "usantça gaixtoa" ( 84 or.) ere hartuaz doalako bekataria.

7. kap. : "guerotic guerora ibiltceaz, coberatcen den usantça gaixtoa" da kapiruluaren haria.

7. kap. - > 8ap.

7. kap.: "Guerotic guerora coberatcen den usantça gaixtoa" ( 86 or.)

8. kap. : "usantça gaixtoac gogortcen eta ez ansiatcen du" (96 or.) bekataria.

Horrezaz gain, bada kapitulu biak tematikoki ere ongi uztartzen dituen pasarte bat VIII. aren bukaera-bukaeran, bien laburpena egiten duena alegia :

"Beraz hunelatan, ezta guerotic guerora, ibili behar. Ezta dembora luceaz beccatutan egon behar. Ceren egoite hura da gure galgarria. handic sortcen da usantça : usantçatic ederestea eder-estetic, ez ansiatcea : ez antsiatcetic ez sentitcea ez sentitcetic, itsutcea, gogortcea, eta azquenean, ahalquea galduric hartçaz preçatcea, loriatcea, eta sendagailla eriztea. Eta handic harat, hartaraz guero [...], gaizqui da hurran da, hillaren pare eguiten da" ( 110 or.)

Gai lotura horien kontraadibide bezala IX. kapitulua jar genezake, besteak beste (halaber, ikus XIVII. kap.). Kapitulu honek bere autonomia propioa du "guerotic guerora" iblitze horretan sor daitezkeen kalteen artean, eta ez du loturarik ez aurreko kapituluarekin ezta ondokoarekin ere. Nolabaiteko gai-loturarik izatekotan, 2. kapitulutik sortuko litzatekeen adarrean koka genezake, hain zuzen ere alferkeriaren beste kalte bat bezala edo.

Baina konektore tematikoak kokaturik dauden lekuaren araberakoak (kapituluen hasiera-bukaerakoak, kapituluak hurrenez hurren lotzen dutenak, alegia) izan badaitezke ere, betetzen duten funtzioaren arabera ere sailka litezke. Hauen artean, arretaz berezi beharko lirateke batik bat gai orokorrera itzularazten duten konektoreak, "gerotik gerora" formularen inguruan eratuta daudenen estilokoak oro har.

Azken hauen eremukoak dira normalean azpimultzoen koherentzia lerroetatik at daudenak eta kapitulu solteetakoak. Dena den, liburuaren enborreko gaiarekin 
lotzen duten konektore hauek bukaeretako peroratio direlakoekin estuki lotuta aurkitzen ditugu gehienetan.

\section{3.- Azken oharkizunak Gero-ren egituraketa orokorraz}

Esan bezala, liburuan barrena Gero izenburuaren araberako batasun antzeko bat somatzen bada ere, esan genezake tematikoki badirela atal desberdinak, sortzeprozesu "propioa" eta berezia izan bide dutenak.

Egia da, dena den, Axularrek berak aitortzen duela -azalean bertan baina zeharka, dena esateko- liburuak izan dezakeen batasun falta hori : "Escritura saindutic, Eliçaco Doctoretaric eta liburu debocinozcoetaric. Axular Saraco errotorac vildua"

"Bildu" hitzak, berez, ez luke derrigorrez antolamendu zehatzegirik adieraziko, eta, gainera, iturri desberdinetako testuei elkarren arteko koherentzia emateko ahaleginak erakutsiko lituzke. Jakina, ahaleginok ez zuten amaierako testuaren erabateko koherentzia ziurtatzen, ez eta hurrik eman ere. Baina, iturriak iturri, liburuak badu koherentziarik aski bere baitan, garaiko askok zutenaren pare bederen.

Beraz, demostraturik geratu uste da barne-koherentziarena baino hutsarte nabarmenagoa dela teorian bigarren liburu bezala proiektatutako harako hari eman behar zitzaiokeen edukiarena : ez ote zen zuen Axularrek balizko hartara honako honetan emandakotik ere eraman behar?.

Izan ere, "bigarrenean kidatzen da, eta aitzinatzen, luzamenduak utzirik, berehala, bere eginbideari, lothu nahi zaikana" delako haren interpretazioa modu hertsiegian ez ote den burutu planteatzen zaio ikertzaileari.

\section{4.- KAPITULUEN BARNE EGITURAZ}

Printzipioz, dispositio delakoaren oinarrian dagoen utilitas irizpidearen arabera, liburuaren egituraketa ezezik, kapitulu guztiena ere, autoreak xedetzat dituenak lortzeko modurik egokienean atondu behar ditu. Irakurle konkretua ikusmiran duelarik, argumentazio mota bezainbeste zaindu behar ditu autoreak argumentatzen duen horren garapena eta aurkezpena, horretatik guztitik, normalean eta teorikoki bederen, nolabaiteko homogeneotasuna sortzen delarik.

Dena den, lehenik eta behin aitortu beharrekoa da Gero-ko kapituluak ez direla espero bezain homogeneoak disposizio alorrean, ez baitira denak berdinak oreka eta egituraketari dagokionez : batzuk bukatu (ago) ak dirudite, eskema klasikoaren arabera edo taxutuak; bestetsuk besterekin loturik doaz eta ez dira hain bukatuak egituraren aldetik, beste horien menpe baitaude ${ }^{20}$, etab.

Aurrekoaren ondorioz, azpimarratu beharrik ez dago, berariaz erabiliko da hemen "multzo" hitza, besteak beste orain hemen interesatzen zaizkigun unitate tematikoek maiztxo kapituluaren mugak gainditzen dituztelako eta inoiz kapitulu gisa agertzen direnak atal gisa ere joan litezkeelako" ${ }^{21}$. Hortaz, zenbaitetan "kapitulu" erabili beharrean "multzo" hitza erabiltzen bada, osotasun tematiko-funtzionalaren zentzuan hartuko da.

Kapitulu huts edota multzo diren unitate hauek badituzte zenbait ezaugarri haien barneko egitura batez mintzatu ahal izateko. Hau da, badute hasierako for- 
mularen bat sarrera moduan eta gaia zentratzeko, inoiz divisio delakoa ere aplikatuko da arazoa argiago uzteko, baina gai-multzo hauen elementurik garrantzitsuena argumentazioa izango da, bertan confirmatio-ak, tesiaren berretzaile gisa eratuko denak alegia, protagonismo nagusia hartuko duelarik. Era berean inoiz confutatio delakoaren arloko funtzioa beteko duten elementuak ere aurkeztuko dira, baina, esan bezala, gehienetan exemplaren bidez baliatuko den konfirmazioa izango da gailenduko dena.

Laburturik eta trinkoturik bada ere, esan daiteke lehen kapituluan bertan ikusten dela garaiko teologiaren metodologia berria eta eragina. Batetik, dialektika eskolastikoa pisua eta indarra galtzen ari da jokabidezko pauta doktrinalen premiaren zabalkuntzaz diharduten obretan ; bestetik, baina aurrekoarekin batera, argumentu arrazionalak tradiziozko argudioei eta auctoritas direlakoei uzten die tokia.

Planteamenduan aurreko guztiaren islada baino ez da izango Axularren obra ; egituran ere, noski, horren oihartzuna atzemango da kapitulu eta unitate tematikoetan zehar. Argumentatze mota "positibo" horien ereduak agerian utziko du sermoien egituraketa tipikoa.

Baina honetan, egia esan, susmatua zuen zerbait Manuel Lekuonak, Axularren sermoilari lana eta Gero-ren sorrera uztartzen hari zor baitzaizkio lehendabiziko hipotesiak :

"Eta, esan-da-egin, mai-bufeta-gañean sermoitarako pillaturik daukan gaiari bestelako jazkera-apur bat eman, eta orra or dana egiña... Zorionean, berri eta berriz ere !

Olaxe sortu-bide zan gure GERO" (Lekuona 1954, xviii) (azpimarra gurea da).

Aurrera doalarik honako hau erantsiko du Lekuonak: "Irakurtzaille arruntak [...] Elizako sermoi-antxa arkituko dio GERO'ren jardunar, gaiez eta eraz" (Lekuona 1954, xxi) (azpimarra gurea da).

Halaz ere, ez zuen zehaztuko zertan zetzan, objektiboki, Gero-ri aurkitzen omen zion "sermoi-antx" hori.

\section{1.- Sermoi egitura eredu}

Axularren liburua arlo suasorio izenekoa da, jenero deliberatiboaren barnekoa. Modu honek xede zehatza bilatu nahi du beti : horren bitartez gizakiak bekatua arbuiatzera iritsi beharko luke eta justizia, pietate eta bertutera makurtu. Eta hori baino ez da Gero-k liburu bezala planteatu eta bilatzen duena.

Egituraketaz den bezainbatean, eta orekak/desorekak gora-behera, Axularren liburuaren kapitulu edo unitate tematikoak oro har sermoietarako ohikoa zen ereduaren arabera moldatu direla esan liteke. Halere, orokorrean horrela planteaturik dagoen arren, kapituluak banaka hartuz gero, erretorika sakratuko liburuetan desberdintzat hartzen ziren moduak nahasian usna litezke zenbaitetan, besteak beste, Krisostomoak askotan erabilitakoaren ildokoak, hots, Ebanjelioaren azalpenerako baliatutakoak, etab.

Baina salbuespenak salbuespen, sermoien egituraketa tipiko horrek Axularten obran dituen ezaugarrien artean, argumentazio ez "silogistikoa" azpimarratuko genuke lehendabizi, eta, bigarrenik, horren ondorioa den garapen mota, non argumentuen agerpenak orden zehatza gordeko baitu : gaiaren planteamendua, normalean pasarte biblikoez baliatuz; patristikaren lekukotasuna tesiaren inter- 
pretazio-konfirmaziorako, eta, azkenik, auctoritas historiae humanae delakoaren arloko exempla : historiagileak, filosofoak... Bukatzeko, argumentatutakoaren ondorioz irakurle-entzuleari egingo zaion eskari zehatza agertuko da, peroratio edo epilogo moduko batek bernean hartuko duena.

Alabaina, Gero-n berehala antzematen da, egituraketa eta distribuzio estilo bat dagoen arren, homogeneotasuna ez dela gehien nabarmentzen den ezaugarria. Agian horregatik pentsatu izan da sarri askotan zailegia dela Gero-n erabiltzen den barne logika eta garapen hariak finkatzea. Oterminek zioenez, "sería muy dificil establecer los esquemas que él emplea en su argumentación y en la trabazón lógica de sus capítulos" (Otermin 1973, 59).

Edonola ere, laster atzematen da konstante antzeko bat liburuan zehar. Izan ere, kapitulu ezberdinetako adibideek argi eta garbi adierazten dute sermoiari dagokion eskema baten aurrean gaudela, bizioen eta bekatuen aurkako gorrotoa eta bertutearen aldeko zaletasuna lortu nahi dituen sermoi tipikoaren aurrean hain zuzen. Formalki ere, ezaugarri nabarmenenak predikarien obra gehientsuenetakoak bezalakoak dira : "en todos tiempos ha sido común que el tema [...] se divida en tres o más puntos principales" (Curtius 1976, 744 : oharra 47), horietako formula errazena honako honetara mugatzen zelarik : sarrera, gorputza eta ondorioak.

Oro har, Axularren liburuaren kapitulu edo unitate guztiak kontutan harturik, guztien azpian ordo naturalis delakoaren haria segitzen da, hots, exordioa-argumentazioa-konklusioa. Zinez esan liteke, beraz, ondoko eskema orokorrera laburbil daitekeela, beti zehatz-mehatz betetzen ez bada ere :

1.- Lectio edo gaiaren aurkezpena (ez beti modu zuzenean egina). Aipamen baten bidez egiten da (aipamen biblikoak batik bat) nagusiki. Zenbaitetan beste autore edo auctoritates batzuez baliatzen da urdazubiarra.

2.- Tractatio edo dilatatio. Gaiaren garapena behar diren elementuez baliatuz egiten da : argumenta (anplifikazioa barne), exempla, konparazioen bidez, etab. Inoiz nolabaiteko divisio thematis ere eskaintzen da tractatio delakoa baino lehenago.

3.- Peroratio edo konklusioan, ohi bezala, gaia zein izan den oroitaraztea eta irakurlearen barnea hunkitzea izango dira xedeak. Elementu desberdinak antzeman daitezke bertan, bataren edo bestearen azentua kapituluen arabera azpimarratuko delarik : laburbiltze edo recapitulatio delakoa, irakurleari zuzendutako galdetegi hunkigarri modukoa, bizimodua edo puntu konkreturen bat aldatzeko eta "konbertitzeko" petitio edo eskaera, etab.

Ikus daitekeenez, sermoiaren egituraketak berbaldiaren ohiko parteen egokitzapena (eta sinpletze moduko bat) ekarri izan $\mathrm{du}^{22}$, predikuak elementu klasiko horietako batzuk soberan baititu bere premiei erantzuteko orduan.

Axularren liburuan zehar, beraz, mezu zehatz baten (= berehalako konbertsioaren beharra eta atzerapenaren ondorio gaitzak) inguruan planteatuko dira kapitulu eta kapitulu multzo desberdinak eta beraietan agertuko dira -gehiago edo gutxiago- berbaldiaren parteak. Narratio delakoa baino askoz ere gehiago landuko da, esaterako, konfirmazioaren arloa, nahiz eta narrazioaren arlo bat ere (exempla-rekin lotua dagoena, hain zuzen) maiz agertuko den. Narrazioaren desagerpenaren arrazoia, erretorika klasikoak bereizten dituen parteekin burutu 
beharreko egokitzapen horretan datza, narrazioak ez baitu tokirik honelako sermoietan. Era berean, konfutazioa edo kontrargumentazioa, oso modu neurtu eta kontrolatuan baino ez da erabiliko, eta gauzak garbi daudenean bakarrik, izan ere irakurle-entzuleengan okerrak eta anabasak sor baitaitezke horrelakoetatik.

Guztiarekin ere, tractatio delakoaren azterketak argumentazioari buruz mintzatzea eskatuko luke eta ez da hau ziurrenik horretarako lekurik egokiena. Alabaina, kapituluen egituraketaren berri izateko interesgarri dirudi lehen eta hirugarren puntuei buruz pare bat ohar egiteak, hau da, kapitulu hasiera-amaierei buruz hain zuzen.

\section{2.- Kapitulu hasierak}

Zuzen edo zeharka, Gero-k dituen ezaugarrietariko bat kapituluak auctoritas biblikoen bitartez hastea da. Esan daiteke kapitulu garrantzitsuenak literalki hasten direla Bibliatik hartutako aipamenekin.

Horretarako erabiliko den formulazio zabalduena honako hau izango da : "Erraiten du [...]-ek" + aipamena. Lehenengo begiradan ikusten den bezala, modu zuzen horrekin hasten dira $3,7,9,10,11,13,14,15,16,45,53$ eta 54. kapituluak. Hain zuzenak ez diren kapitulu hasierak ere badira, hots, "erraiten du" delakoa iruzkin labur baten ondoren kokatzen dutenak (49. kap., etab.)

Normalean "errailea", lekukotasunaren balioak hala aginduta, Izpiritu Saindua ohi da. Formula desberdinez baliatzen da Axular : "Erraiten du Salomonek, edo Salomonen ahotik Spiritu Sainduak [...]" (45 or.), "Erraiten du Salomonek, Iainkoarekin mintzo dela [...]" (111 or.), "Erraiten du Spiritu sainduak [...]" (170 or.), "Erraiten du eskritura sainduak [...]" (184 or.)

Dena den, gaia planteatzerakoan "errailea" zalantzarik sortzen ez duen auctoritas bat ere izan daiteke : "Erraiten du san Thomasek [...]" (419 or.), "Erraiten du San Thomas Doktor handi hark [...]" (548 or.). Ildo horretatik, sintomatikoa da Jainkoaren miserikoardiaren beharraz eta fidantzia horren soberaniaz tratatzean (10. eta 11. kapituluek osatutako azpimultzoan), Axularrek dakartzan lekukoak: "Erraiten du San Thomasek [...]" (127 or.) eta "Erraiten du San Agustinek [...]" (133 or.). Trentoko Kontzilioak ere badu ohorezko tokia, nahiz eta sarrera labur baten ondoren : "Hala erreiten du Konzilioak [...]" (454 or.). Seneka "kristauak" ere badu bere tokia kapitulu atari batean : "Erraiten du Senekak [...]" (194 or.).

Zeharkako bidea ere erabili izan da kapitulu hasieretan. Lehenengo kapituluan, esate baterako, Hasiera liburutik jasotako pasarteak ${ }^{23}$-behar zenerako egokituta- zuzenean euskaraz ematen dira, sarrera moduan edo bailiren. Baina, aitortu beharrik ez da, gaia hobeto planteatu ahal izateko erabili da bide hori, zeren eta berehala ematen baita latinezko aipamen zuzena, eskritura sakratuetan hasierako pasartearen jarraipena dena.

Antzeko zerbait esan beharko litzateke VI. kapituluari dagokionez, Bibliako konparazio batez hasten baita : Anhitzetan ere eskritura sainduan, konparatzen da bekhatorea, ardi errebelatuarekin [...]" (78-79 or.). Eta berdintsu XIX. kapituluari buruz ere, bertan konparazio bibliko batez ekiten batzaio kapituluari : Nola gure lehenbiziko aita hark, gure naturaleza haur, bere bekhatuaz narriatu [...]. Handik gara [...]" (250 or.). 
Nolanahi ere den, sermoietan bezalaxe, kapituluen hasieran ongi eta irmo gordetzen da erretorika eklesiastikoa garatzen saiatu zirenek eman ohi zuten aholkua : "nunca se comience con fábula, geroglífico ni poesía, porque esto es contra la gravedad de aquel acto sagrado darle tan ruin principio [...]. Sea, pues, el principio una autoridad de la Escritura o de un Santo o una buena razón" (Terrones del Caño, 109 or.).

Hasiera motei dagokienez, beste kapituluetan kasuistika anitza aurki badaiteke ere, badira batzuk esanguratsu eta aipagarri direnak.

Zenbaitetan gai-unitatearen dependentzia nabaria agertzen da. Adibidez, II. kapituluak (esana dugu jadanik lehenengoarekin nolabaiteko multzo tematikoa osatzen duela) lotura formala ere adieraziko luke lehenengoarekin, harekiko lotura bigarren honek hasieran bertan lehenaz egiten duen laburpen edo recapitulatio batean $^{24}$ finkatzen baita :

"Eskritura Sainduak, Elizako doktorek, lehenagoko ientilek, eta are zeruko, aireko, eta lurreko gauza guztiek ere kondenatzen dute alferra, eta emaiten aditzera behar dela trabaillatu, eta nor bere aldetik bere eginbidearen egitera enseiatu. Zeren nola ardurako trabailluak, lan guztiak aitzinatzen baititu, hala alferkeriak gibelatzeintu" ( 37 or.)

Aipagarria da, bestalde, Axularrek maiz egiten dituen esplanazio antzekoak. Aurrekoen dependentzia tematikoaren pean dauden kapitulu zenbaitek areagotu egiten dute azaldu nahi dena, areagotu eta elementu berriak ekarri ere bai (divisio delakoren laguntzaz, esaterako). 16-18 multzoan, esaterako, hori baino ez da gertatzen. Sailkatze eskolastiko horren adibide zehatza 56-57. kapituluetan genuke ; halaber, nahiz eta beste maila batekoak, 52. kapituluan eta kalte-erremedioez dihardutenetan ere.

Ez dira gutxi, azkenik, modu dialogikoan planteaturik, egilearen hausnarketa, laburpen, azalpen edota petitio antzeko batez hasten diren kapituluak, horietako zenbait, gero, lekukotasun bibliokoen arlora iristen badira ere. Normalean, gaia ahalik zehatzen zentratzea izan ohi da horrelakoen funtzioa (ikus bitez, besteak beste, honako kapitulu hauek : 4, 12, 17, 48, 55, etab.).

Bukatzeko, gogoratu baino ez, kapitulu hasierak gora-behera, gai bakoitzaren garapenean erabiltzen den sistema induktibo-argumentala garaiko teologiak ezarritako ereduetatik abiatuko dela.

\section{3.- Kapitulu amaierak}

Ezaguna da genero suasorioko liburuak, sermoiak eta ildo horretako diskurtsuak bezalaxe, peroratio batez bukatzen direla. Formalki, barrenean, bukaera iristerakoan, peroratio horrek entzule/irakurleari (haien gogorari, hobe) zuzendutako petitio edo eskaera bat eraman ohi du. Jakina, aszetikakoetan jainkoaren itzalpean jar dadin eskatzen zaio mezu-hartzaileari. Artazak oroitarazten duen bezala, "la petición insta al alma a modificar su conducta hacia « lo útil » y « conveniente » -loci obligados en toda deliberación" (Artaza 1988, 316)

Axularren liburuan ere eskaera irakurlea konberti dadin egiten da. Baina ez behin bakarrik eta liburuaren amaieran, etengabeko modu errepikakorrean baizik. Liburuaren izaerarekin bat eginik, kapitulu-multzo, azpimultzo eta kapitulu solteen bukaeran ere errepikapenaren mailuak "berehala konbertitzera" gonbidatuko 
du, batzuetan formula desberdinak erabiltzen badira ere (gerotik gerora ibiltzeari uzteko premia, etab.). Normalean, perorazio direlako hauek sententzia edo sententzia bezalako esaldi laburbiltzaileren bat ${ }^{25}$ eraman ohi dute irakurlearen baitako hunkipena areagoturik gera dadin (ikus ondoko adibideetan).

Alabaina, peroratio horien gainazterketak erakusten duen bezala, beste funtzio garrantzitsu bat ere betetzen dute esku artean dugun liburuaren koherentziaren esparruan, izan ere, bukaerok faltan dirudien koherentzia-emaile gisara erabiltzen baitira maiztxo. Horrela, peroratio errepikakor horiek liburuaren enbor tematikotik gerta daitezkeen (eta gertatzen diren) aldegiteak txertarazten ditu behin eta berriro "Gero" (liburua eta mezua) delakoaren inguruan.

Horrezaz gain, egia da gurearen kapitulu batzuk askoz ere modu borobilagoan bukatzen direla liburua bera (azken kapituluarena, alegia) baino eta horrek anabasaren hipotesia areagotu egin izan duela ikertzaile askorengan. Adibidez, honek berak markatu zuen, besteak beste, kapitulu batzuen kokapen berria Lafitte eta Intxausperen berrantolamenduetan. Azken honi, esaterako, liburua amaitzeko, tematikoki XLVII. kapitulua eta, formalki kapitulu horretako bukaera egokiagoak iruditu zitzaizkion, G. Milangesek inprimatuak baino:

"Fineraino eta finean perseberatzen duena, izanen da salbatua eta ongi zortheatua. Qui autem perseveraverit usque in finem, hic salvus erit (Mt. 10). Bertze guztiak deus guti dira, finak darama koroa, akhabatzean kantatzen da loria.

Beraz fin hari, eta akhabatzeko loria hari begia edukirik, hareraiño, eta han, behar dugu, egun beretik, geroko begira egon gabe, bekhaturik gabe egoitera enseiatu. Hartarakotzat orai eskuen artean darabiltzagun bekhatuak urrikimendu handi batekin kofesaturik eta utzirik, aitzinerat gehiago egitetik begiratzen garela. Zeren halatan erdietsiko dugu orai perseberantziaren donua eta gero azken finean arimen salbamendua, sekulako loria" (474 ог.)

Peroratio direlako hauetan konstante bat izango dira petitio-ei sarrera emateko ia salbuespenik gabe agertuko diren elementu formalak. Oro har, "beraz" lokailua izango da gehien agertuko dena, kapitulu gehienen bukaeran hain zuzen. Alabaina, sarri askotan "beraz hunelatan" formulaziopean agertuko da : 8, 10,11, $13,15,23,29,34,38,42,45,50,53,54,55$ eta 60 . kapituluetan.

Baliabideen artean, ikus daitekeen bezala, ez da faltako frekuentazioa ${ }^{26}$ bezalako pentsamendu irudia.

Guztiarekin ere, eta argigarri gerta daitekeelakoan, bukaera mota desberdinei buruzko bi hitz erantsi nahi genituzke hemen.

Lehendabizi kapitulu-multzoen bükaerak azpimarratu nahi genituzke, izan ere kapitulu bakoitzak normalean berea duen arren, batzuetan kapitulu-multzoek bukaera komuna agertzen baitute, multzoaren osotasuna erakutsiz. Horretaz aparte, irakurlea erraz ohar daitekeen bezala, hainbat bukaerak etenketa bortitza dakarkio testuaren koherentziari.

Kapitulu-multzoetan bezalatsu, azpimultzo deitu izan ditugun horietako zenbaitetan ere bukaera komunak agertzen dira ezaugarrien artean. Kapitulu bakoitzak normalean bere amaiera mota duen arren, batzuetan azpimultzo osoaren azkenak bukaera laburbiltzailea ager dezakete. 
Era berean, eta gorago azaldutakoaren haritik, modu berezian azpimarratu nahi genuke azpimultzoetako amaierek betetzen duten koherentzia funtzioa, besteetan baino nabarmenago ikuslen baita egiteko hori.

Azkenik, kapitulu solteetan aurkitzen diren konektore tematikoak normalean "gerotik gerora" formularen inguruan eratuta daude eta liburuaren gai orokorrarekin uztartzen dute kapitulua, tituluko Gero-ri baitiote erreferentzia etengabe egiten. Konektore hauek, zer esanik ez dago, kapitulu amaieran (ez beti peroratio-an) txertatuta aurkitzen dira gehienetan.

\section{5.- ONDORIO GISAKOAK}

Axularren liburuaren egituraketaren esparruan egia da "eklektizismo" moduko bat izango dela ezaugarri, batik bat gaien antolamenduari dagokionez. Zinez pentsa daiteke zenbait kapituluk edo kapitulu-multzok unitate erabat independienteak osatzen dituztela eta aurre-atzekoekin lotuak izateko "aukera" -ezin baikenuke egungo "koherentzia" irizpidea erabili- liburuaren gaiaren zabaltasunak berak emana dela ("gero"-ren ingurukoak, alegia).

Gogoratu, bestalde, Axularren testu-antolamenduaren "anabasa" horren oinarrian, kapituluen bideratzaile gisa agertzen diren jatorri desberdineko testuak daudela. Antolamenduak nolabaiteko koherentzia bilatu nahi izan du, behinik behin kapituluen artean.

Era berean, testuan sakabanaturik antzematen diren iturri desberdinetako pasarteak eta testuaren tonu errepikakorra bera direla eta, zenbaitetan areagotu egiten da irakurlearengan logika faltaren inpresioa. Alabaina, gabezia hori egituran baino lehenago sormen-lanaren linealtasunaren faltan bilatu beharko litzateke nagusiki. Ziurrenik, materiale ugari horiekin egin zitekeen obrarik koherenteena egin baitzuen urdazubiarrak, eta zalantzarik gabe azken mende eta laurden honetan egin diren antolamendu berriak baino koherenteagoa.

Airean geratzen da, dena dela, obra bi parteetan eman nahi izanaren arazoa. Izan ere, bestelako elementurik (lekukotasun historikoak, testuak, etab.) ez den bitartean, badirudi nekez aurki daitekeela liburuan bertan arazo horren argitzaile izan litekeen aztarnarik.

Kapituluen barne egiturari gagozkiolarik, klarki geratu da Axularrek predikarien ohiko egituratzeaz tindatu zituela obraren unitate desberdinak, atalek "tesiagarapena-amaiera" eskema sermonarioari jarraituko diotelarik. Bereziki aipatu ez bada ere, oroitu beharrekoa da exempla-ren atalak argumentazioaren garapenean hartzen duen garrantzia.

Oro har, beraz, kapituluek ohiko sermoien pareko garapena erakusten dutela esan daiteke, hots, tesia oinarritzeko aipamena (biblikoa maiz asko), inoiz divisio -a, eta batik bat, exemplaren bidezko argumentazio eskuarki baieztatzailea edo konfirmatiboa. Egituratze honetan garrantzi handia izango du peroratio delakoak. Azken orduko hitzen balioa irakurlea hunkitzeko eta haren jokamoldea aldarazteko baliabideen arabera neurtu ohi baita. Esan bezala, bukaerak perorazio arlokoak dira eta askotan, ohi bezala, eskaera zehatza daramate txertaturik, irakurleari konbertitzeko edota bide onean jartzeko dauden modalitate desberdinetako eskaera eginez. 


\section{BIBLIOGRAFIA}

Arellano, Ignacio, 1991, "Edición crítica y anotación filológica en textos del Siglo de Oro. Notas muy sueltas" in Arellano, I. eta Cañedo, J. (ed.) 1991, 563-586.

Arellano, 1. eta Cañedo, J. (ed.), 1991, Crítica textual y anotación filologica en obras del Siglo de Oro. Actas del Seminario Internacional para la edición y anotación de textos del Siglo de Oro (Pamplona, Universidad de Navarra, Abril 1990), Madrid, Ed. Castalia.

Axular, Guero, Bordele, 1643 (faksimila : Bilbo, Euskaltzaindia, 1988).

Curtius, Emst Robert, 1976, Literatura europea y Edad Media Latina, 1 eta 2, Madrid, F.C.E. (1 ed. : Europäische Literatur und lateinisches Mittelalter, Bema, A. Franke, 1948).

Granada, Luis de : Guía de Pecadores, Lisboa, Joannes Blavio de Colonia, 1556 (lehen edizio hau orain : Madrid, Espasa-Calpe, 1953 ; edizioa, hitzaurrea eta oharrak : Matias Martínez Burgos)

, Guía de Pecadores, in Obras del VP.M. Fray Luis de Granada, I, Madrid, Imprenta de la Publicidad (BAE VI), 1944, 1-470 or.

, De la Oración y Consideración, (De la Oración y Meditación libunua, hain zuzen) in Obras del VP.M. Fray Luis de Granada, M, Madrid, Imprenta de la Publicidad (BAE VIII), 1945, 1-202 or.

, Retorica Eclesiástica o de la manera de predicar, in Obras del VP.M. Fray Luis de Granada, III, Madrid, Imprenta de la Publicidad (BAE XI), 1945, 488-642 or.

, Memorial de la Vida Cristiana, in Obras del VPM. Fray Luis de Granada, I, Madrid, Imprenta de la Publicidad (BAE VIII), 1945, 203-411 or.

, Adiciones al Memorial de la Vida Cristiana, in Obras del VPM. Fray Luis de Granada, II, Madrid, Imprenta de la Publicidad (BAE VIII), 1945, 412-611 or.

Inchauspe, M., 1864, "Aitcinsolhasa" in Axular: Gueroco guero, 3. edizioa (Inchausperen edizioa).

Lafitte, P., 1943, "GERO-aren bilduma", in A.A. : Axular 1643-1943 (Troisième Centenaire du Guero)," 25-29.

, 1956, "Axular'en liburuaz", Gure Herria XXVIII-6, 341-344.

Lekuona, Manuel, 1954, “Aitzin-solas", in Axular : Gero, 4. ed., IX-XXXII or.

Maingueneau, D., 1987, Nouvelles tendances en analyse du discours, Paris, Hachette.

Oleza, J., 1981 , "La Literatura, signo ideológico" in Romera Castillo (koord.) : La literatura como signo, Madrid, Playor.

Otermin, A., 1973, Aproximación al ritmo de la prosa de Axular, Deustoko Unibertsitatea, Lizentziatura tesina.

Terrones del Caño, Fco., Instrucción de Predicadores, Granada, 1617, [orain : Olmedo (ed.) 1960, Madrid, Espasa-Calpe].

Urquijo, Julio de, 1912, Una fuente del Guero (Axular imitador de Fr. Luis de Granada), 12 orrialdetakoa, Saint Jean de Luz : J. Dargains. 


\section{Notes}

1. Exordioaren funtzioa bi maila desberdinetan ematen da liburuetan eta ez da bata bestearekin nahasi behar : alde batetik, liburuaren exordio orokorra legoke, hitzaurrean doana, eta, bestetik, unitate bakoitzeko gaia aurkezteko sarrera edo aurkezpen modukoa.

2. Ez da ahaztu behar "itxura" horretan oinarritu izan direla Axularren egiletzaren zalantza eta bestelakoak ere, batik bat editorearekin liburua apailatzeko azken ardura zalantzan jarri diotenen planteamenduak : Axularrek berak izendatutakoren bat izan ote zen?, haren iloba dglan?, editırea ?,...

3. Beste modu batez esanda, "[...] des morphèmes qui ont pour fonction de lier deux énoncés" (Maingueneau 1987, 117).

4. Parentesi artean jarri dira Gero liburuaren lehenengo edizioari dạn/kion kapitulu-zenbakiak.

5. Parentesi artean, zenbaki erromatarru; idatriak, dagokigun liburuaren lehen edizioan kapituluek daukaten kapitulu zenbakia jarriko da.

6. Gehiagotan ere agertuko da : "liburutto hunen, kanporat atheratzeko, ausartziaren hartzera" (4 or.), "Liburutto haur da emazurtza" ( 4 or.), "Ediren budi liburutto hunetan ( 10 or.), "Eztut liburutto haur letratu handientzat cyiten" ( 19 or).

7. Honekin azaleko konstatazio huts bat baino ez dugu egin nahi, azterketa estilistikoak honelakoetan eskain dezakeena berez erlatibizatzen baita gure oharren beharrik gabe. Ez gara, beraz, egiletzaren arazoan sartzen. Edonola erc, zz legoke soberan Arellanok csandakoak gogora ekarzea : "muchas supucstas marcas de autor son rasgos comunes y generalizados de un fondo mostrenco; y los rasgos idiolectales o son poco relevantes o mucho; cuando son poco no son demasiado significativos ; cuando son mucho resultan fácilmente imitables" (Arellano 1991, 566, oharra).

8. Honen guztiaren adibide konkretua haren Guia de Pecadores obraren bigarren liburua izango genuke

9. Bigarren liburu honetan Granadak batetik bizio hedatuenak eta erremedioak azalduko ditu eta, bestetik, bertuteak.

10. Oro har, azpimarratutako hitzek kapituluetako tituluetakoak direla adierazten dute.

11. Gogoratu protestanteen "fedearen bitartez, salbazioa" delako planteamendua. Hemen horren aurka egiten da, ikusten denez.

12. 149 or.

13. 154 or.

14. 192 or.

15. 199 or.

16. Aurreko kapituluekiko lotura hau 522. orrialdeko ondorio gisako horretatik atera bide daiteke, nekez bada ere. Hori bai, 48. kapituluaren idazpurua ez dator bat kapituluarekin, alderantziz baizik (474 or.), ez eta "gerotik gerora ibiltzea" delakos ere, behin ere ez baita testuan zehar honen erreferentziarik egiten, harik eta 522 orrira iritsi arte.

17. Lehenengo liburuan, esaterako, hin parte agertuko dira Granadakoarenean : bertutearen beharraz eta hartaratzeko arrazoiez arituko dena ; azkenkiak ere lehenengo honetan tratatuko dira : heriotza, epaia, paradisua eta infernua. Bigarren partean beste arrazoi batzuk aurkeztuko dira : bizitza honetan bertutearen bitartez eskuratuko diren pribilegioak hain zuzen. Hirugarrenean "se responde a todas las excusas que los hombres viciosos suelen alegar para dar de mano a la virtud" (Granada, Guia, 14 or.). Axularrenean gai berdinek, bistan da, beste antolamendu bat izateaz gain, beste pisu eta tratamendu bat dute.

18. Ondoko zerrendan agertzen ez diren kapituluek berezko autonomia izango lukete haiek bakarrik, nahiz eta askotan nolabaiteko lotura ternatikoa ere izan dezaketen aurreko-ondokoekin.

19. Maingueneauren konstatazioa abiapuntutzat ("En général, les théories de I'argumentation oscillent entre une conception «logiciste » et une conception "rhétorique " [Maingueneau 1987, 1 16), bugi bista- 
koa da konektoreen planteamendu honetan ikuspuntu logiko-erretorikoa uztartzen saiatu garela, zeharo gramatikalak direnen kaltetan.

20. Hau da, esaterako, "erremedio" izena daramaten kapitulu askoren kasua.

21. Besteak beste, XXV. kapituluaren kasua : egia esan, hogeitaseigarrenaren barruan ere joan zitekeen, bai duen laburtasunagatik, bai erremedio motagatik ("ona da kontsideratzea...").

22. Teoria erretorikoaren arabera, honako hau zen obra bukatuen eskema nagusia : exordioa, narratioa, divisioa, confirmatioa, confutatioa eta conclusio delakoa.

23. Gogora dezagun Gero liburuaren lehen kapitulu hau paradigmatikoa izan daitekeela (argigarrien:i delako. hain zuzen) argumentuen mailaketari dagokionez: Hasiera izeneko liburu biblikotik hartutako pasarte bat abiapuntutzat, tradizio eta patristikaren argitan aztertzen da, auctoritas historiae humane delakoak ere bere adibide sorta eskaintzen duelarik.

24. Sarrera moduko hau, dena den, erraz asko joan zitekeen aurrekoaren bukaera gisara ere.

25. Recapitulatio delakoaren funtzioa beteko luketen esaldiak ohi dira hauck, irakurlearen oroimena freskatzeko prestatuak eta ondoren eskatuko zaienarekin lotzeko ezin hoheak -labur eta tinko kondetsatzen baitute esandakoa.

26. " [...] usar de esta figura en el fin del sermon, principalmente en los suasorios, cuando todos los argumentos que propusimos en el discurso del sermon los juntamos brevemente en uno, para que con todos ellos de un golpe asaltemos los ánimos del auditorio, y en cierto modo los violentemos.

$\mathrm{Y}$ no solo en el fin del sermon será bueno refrescar la memoria de los oyentes con esta misma figura, sino tambien en sus partes, do quiera que se concluyere alguna disputa ó argumento largo" (Granada, Retórica, 588b ; lerropekoak gureak dira). 